\title{
Impacts of forests and forestation on hydrological services in the Andes: A systematic review
}

\author{
Vivien Bonnesoeur (1), Bruno Locatelli (1,2), Manuel R. Guariguata (1), \\ Boris F. Ochoa-Tocachi $(3,4,5)$, Veerle Vanacker (6), Zhun Mao (7), \\ Alexia Stokes (7), Sarah-Lan Mathez-Stiefel $(8,9)$
}

1: Center for International Forestry Research (CIFOR), Lima, Peru

2: Agricultural Research for Development (CIRAD), University of Montpellier, France

3: Imperial College London, Department of Civil and Environmental Engineering \& Grantham Institute - Climate Change and the Environment, London, United Kingdom

4: Regional Initiative for Hydrological Monitoring of Andean Ecosystems (iMHEA), Lima, Peru

5: Institute for Applied Sustainability Research (iSUR), Quito, Ecuador

6: Earth and Life Institute, Georges Lemaître Centre for Earth and Climate Research, Universite Catholique de Louvain, Louvain-la-Neuve, Belgium

7: Amap, Inra, Cnrs, Ird, Cirad, University of Montpellier, Montpellier, France

8: Centre for Development and Environment (CDE), University of Bern, Bern, Switzerland

9: World Agroforestry Centre (ICRAF), Lima, Peru

Paper published in Forest Ecology and Management (2019), Vol 433, pp.569-584

https://doi.org/10.1016/j.foreco.2018.11.033

CC-BY-NC-ND license (Creative Commons Attribution-NonCommercial-NoDerivs)

Acknowledgments: The funding partners that have supported this research include the European Union's H2020 research and innovation program (SINCERE project, grant agreement No. 773702), the International Climate Initiative (IKI) of the German Federal Ministry for the Environment (BMUB), the Norwegian Agency for Development Cooperation (NORAD), the U.S. Agency for International Development and the Government of Canada (Green Infrastructure for Water Security), and the CGIAR Research Program on Forests, Trees and Agroforestry (CRP-FTA) with financial support from the CGIAR Fund. The authors also thank the two anonymous reviewers for their useful comments. 


\section{Abstract}

Several Andean countries have planned to restore forest cover in degraded land to enhance the provision of multiple ecosystem services in response to international commitments such as the Bonn Challenge. Hydrological services, e.g. water supply, hydrological regulation and erosion mitigation, are particularly important to sustain the life of more than fifty million Andean people. While rapid and important forest cover changes have occurred during recent decades, critical information on the impact of forestation on hydrological services has not yet been synthesized in the context of Andean ecosystems. We define forestation as the establishment of forest by plantation or natural regeneration on areas that either had forest in the past or not. To help improve decision-making on forestation in the Andes, we reviewed the available literature concerning the impacts of forestation on water supply, hydrological regulation and mitigation of erosion and landslides. We also examined available data on the most relevant hydrological processes such as infiltration, evapotranspiration and runoff in forest stands. Hydrological services from native forests were also included as a reference state for comparing processes and services provided by forestation. Following systematic review protocols, we synthesized 155 studies using different methods, including meta-analyses and meta-regressions. Results show that forestation has had clear impacts on degraded soils, through reducing water erosion of soils and risk of moderate floods, increasing soil infiltration rate by 8 and topsoil organic matter (SOM). We found that 20 years of tree plantation was sufficient to recover infiltration rate and sediment yield close to the levels of native forests whereas SOM, soil water storage and surface runoff of native forests could not be recovered by forestation in the time scales examined. The benefits in terms of hydrological regulation are at the expense of a reduction in total water supply since forest cover was associated with higher water use in most Andean regions. Forestation with native species was underrepresented in the reviewed studies. The impact of forestation on landslides has also been largely overlooked in the Andes. At high elevations, exotic tree plantations on Andean grasslands (e.g. páramo and puna) had the most detrimental consequences since these grasslands showed an excellent capacity for hydrological regulation and erosion mitigation but also a water yield up to $40 \%$ higher than tree plantations. People engaged in forest restoration initiative should be aware that hydrological services may take some time for society and the environment to show clear benefits after forestation. 


\section{Introduction}

Forest cover is an important driver of water availability at both local and global scales (Ellison et al., 2017). Syntheses of global data have shown that water use by forests, and especially plantations of fast-growing tree species, may reduce water availability for human consumption or other uses (Farley et al., 2005, Jackson et al., 2005, Zhang et al., 2001). Nevertheless, forestation (defined in this review as the forest establishment on previously non-forested land without consideration of the past forest cover Malmer et al., 2010) can reduce water erosion of soils and may promote hydrological regulation e.g., conserving low river flow during dry seasons and reducing floods (Bruijnzeel et al., 2004, Ilstedt et al., 2007, Labrière et al., 2015). However, as the hydrological consequences of forestation depend on specific combinations of local parameters such as climate, vegetation, soil, and topography, they cannot be extrapolated from one region to another.

In the Andean region, the hydrological impacts of forestation have received limited attention, despite their importance (Filoso et al., 2017, Ochoa-Tocachi et al., 2016b). More than fifty million people depend directly on services provided by diverse Andean ecosystems (Doornbos, 2015; Cincotta et al., 2000). Ecosystems such as páramo or puna grassland and cloud montane forests supply water not only to local communities but also to dry regions along the Pacific coast (Célleri and Feyen, 2009, Tobón, 2009). Andean natural ecosystems also play an important role in controlling water erosion and floods and in stabilizing soils against landslides in steep terrain (Bathurst et al., 2010a, Guns and Vanacker, 2013).

Nevertheless, the rapid and important forest cover changes during the last few decades have deeply modified the provision of hydrological services (Jones et al., 2017, Ponette-González et al., 2014). Deforestation began several centuries ago and has been accelerated in the last five decades, resulting in a considerable drop in the total area covered by Andean forests to $<10 \%$ of their original cover (Balthazar et al., 2015, Chepstow-Lusty and Winfield, 2000, Jones et al., 2017). Simultaneously, natural forest regeneration has occurred on abandoned agricultural land, and fast-growing exotic species (e.g. Eucalyptus spp. and Pinus spp.) have also been planted on degraded agricultural land and high altitude grasslands for fuelwood supply (Aide et al., 2013, Ponette-González et al., 2014). While some plantations have successfully grown on eroded slopes and improved initial degraded conditions, others have generated conflicts due to decline in water yield, especially when trees were planted on well conserved grasslands (Buytaert et al., 2007, Farley, 2007, Morris, 1997, Ochoa-Tocachi et al., 2016a, Torres-Salinas et al., 2016). The ability of exotic species plantations to reduce water erosion has also been questioned by several studies, which suggested that agricultural terraces were more efficient in reducing water erosion than e.g., Eucalyptus spp. plantations (Harden, 1992, Inbar and Llerena, 2000).

Overall, very few studies have synthesized the consequences of forestation on hydrological services in the Andes. We address this issue through a systematic review and a meta-analysis of the existing literature to inform decision making and land management 
with solid scientific evidence. Systematic reviews have become a recognized standard for synthesizing scientific information in health and environmental disciplines (Collaboration for Environmental Evidence, 2013) and meta-analysis is useful to statistically combine findings from different studies to generalize conclusions (Locatelli and Vignola, 2009). We reviewed and synthesized scientific publications and unpublished theses on the impacts of forestation (including tree plantation and natural forest regeneration) and forest cover change on water supply (i.e. streamflow and groundwater), hydrological regulation, water erosion control and landslide mitigation in the Andes (Fig. 1). We included mitigation of water erosion and landslides because they cause river water turbidity and are driven largely by soil hydrology (Brauman et al., 2007, Payeur-Poirier and Nguyen, 2017). We also examined available data on several hydrological processes (such as rainfall infiltration, evapotranspiration and soil water storage). We also included studies comparing native forests with other types of land use, as they give insights into the state of reference of hydrological services provided by forests, to which forest restoration can be compared (Bullock et al., 2011). In the context of the recent international initiatives promoting the restoration of degraded and deforested lands in Latin America (Bonn challenge and the 20x20 Initiative) (IUCN, 2011, World Resources Institute, n.d..), this approach is particularly valuable to inform decision making on land and ecosystem management, such as the paradigm of forest landscape restoration (Sabogal et al., 2015) which is high in the policy agenda of most Andean countries and represents an opportunity to increase the provision of forest-based services (IUCN, 2011, Murcia et al., 2017).

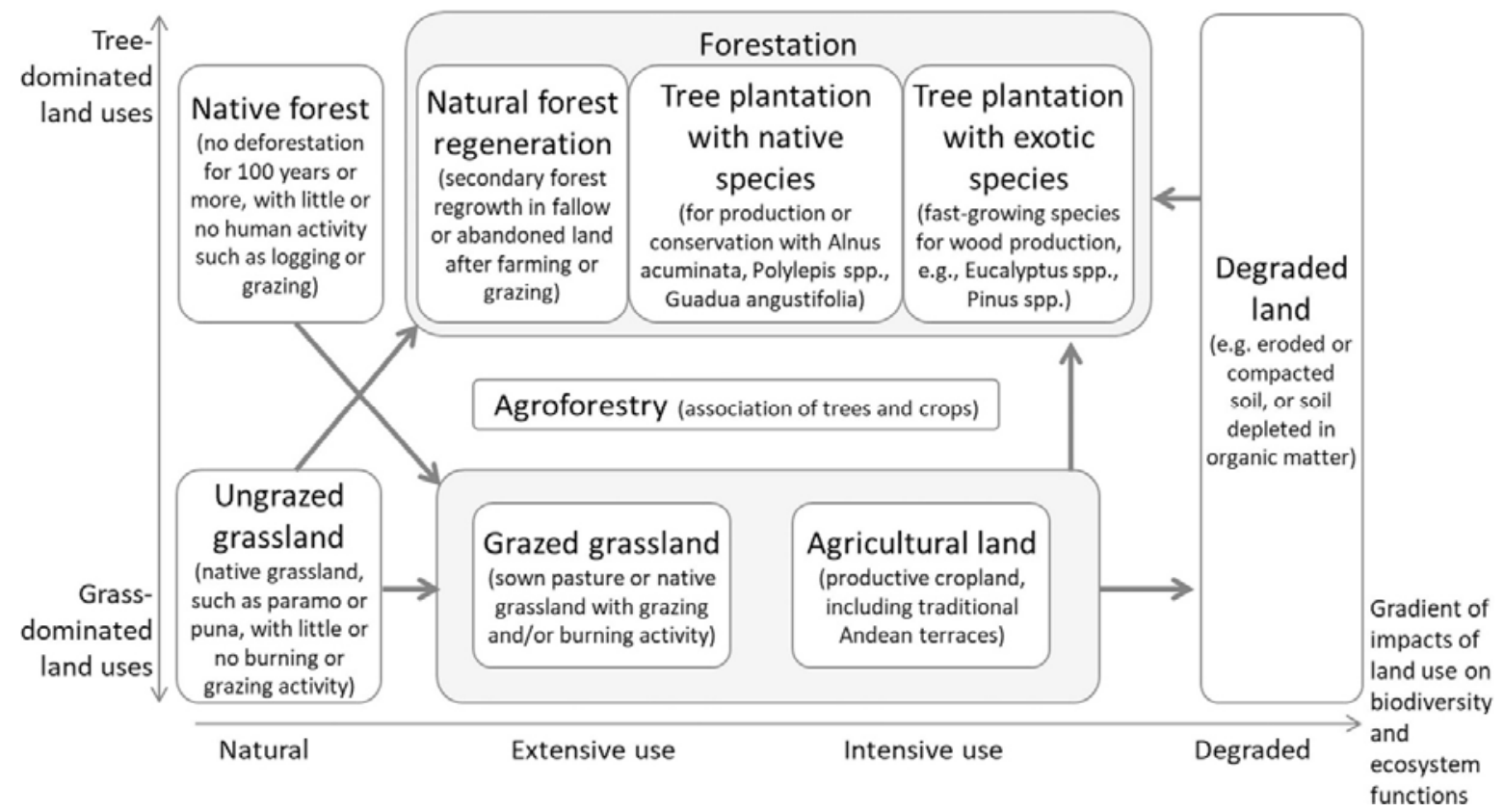

Fig. 1. Land use types and land-use changes (arrows) used in this review. Forestation is the forest establishment on non-forested land without consideration of the past forest cover. Degraded soils are represented for conceptual purpose although they are not considered a land use. 


\section{Materials and methods}

\subsection{Search protocol}

We searched peer-reviewed journal articles and book chapters in three academic databases: ISI Web of Science, Scopus, and Ovid (the latter includes AGRICOLA and CAB Abstracts). We also tested different databases to ensure the completeness of our searching (supplementary material SM1). The search terms combined four groups of terms (in English and Spanish) with logical operators: "Andean site" AND "Forest cover change" AND ("Water variables" OR "Soil variables") (details in supplementary material SM2).

We then enlarged our search by (i) using Google Scholar for "citation chasing": i.e., within the documents that cited papers we identified as influential, we searched for those that focused on the Andes, (ii) browsing the online libraries of regional organizations related to natural resources or sustainable development in the Andes region, (iii) searching PhD and Master level theses from selected universities in Andean countries, using the same search terms as those used when searching the international databases (see details in supplementary material SM3).

\subsection{Study selection}

We applied two filters to the $4000+$ records found. A first filter on titles and abstracts selected 450 records, of which only 291 full texts were retrieved (Fig. 2). This filter was conservative in order to retain articles in case of doubt as to whether all the selection criteria were met. A second filter on full texts resulted in a final set of 155 studies. The filters considered three criteria: (i) Andean location, (ii) included information on tree plantation or natural regeneration characteristics and (iii) studied outcome in terms of soil or water variables. A few studies were rejected when the quality of data, data sources or general information provided, was poor. 


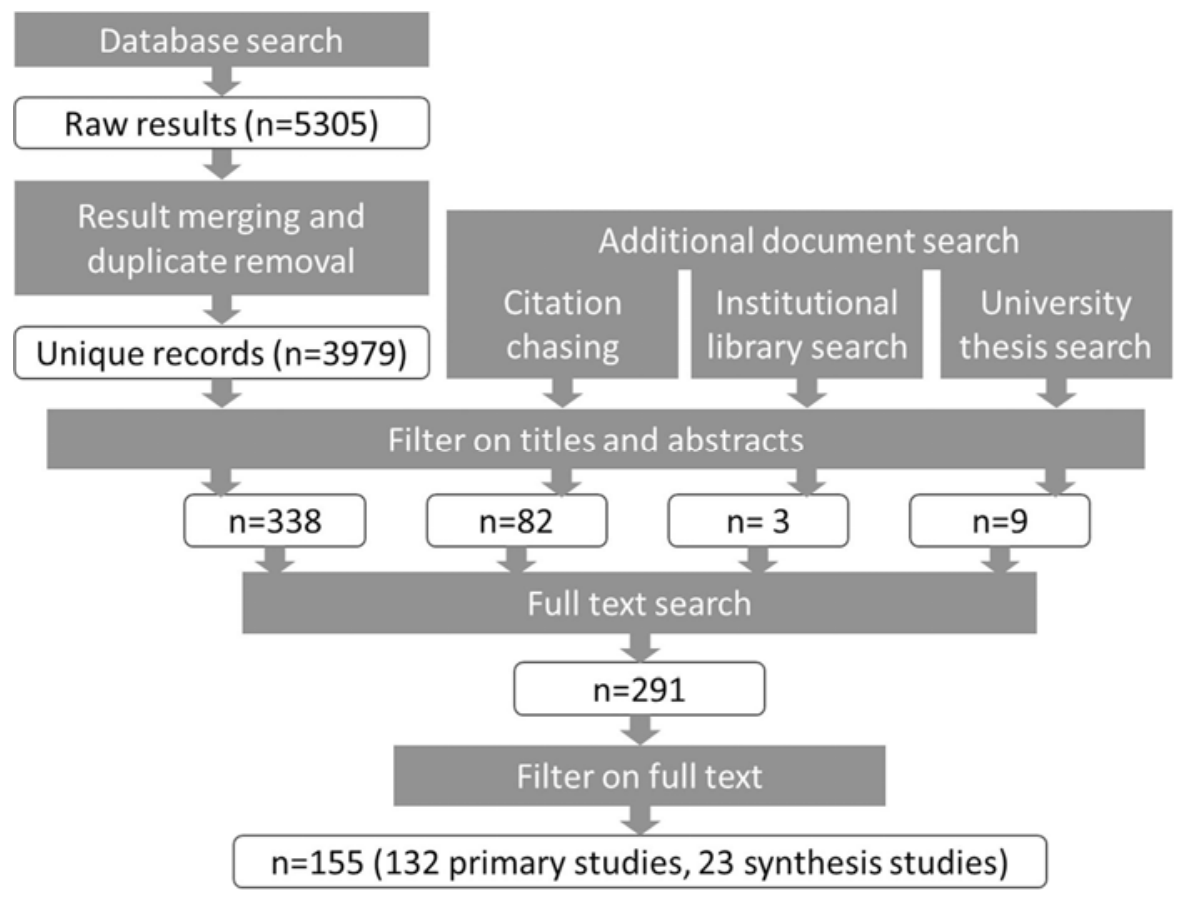

Fig. 2. Stages of study search and selection, with numbers of studies (n) at each stage.

Concerning criteria (i), we retained studies within the altitudinal range between $600 \mathrm{~m}$ above sea level (a.s.l.) and the treeline (Josse et al., 2011). The treeline ranges from $2000 \mathrm{~m}$ in the southern Andes to $4500 \mathrm{~m}$ in the northern Andes, although scattered patches of Polylepis spp. trees can be found at 5000 m.a.s.l. (Josse et al., 2011, Kessler, 2002) Actually, it is often acknowledged that páramo and puna ecosystems could be substantially more covered by forests and treeline is difficult to define in these region (Sarmiento and Frolich, 2002). In practice, we retained studies up to 5000 m.a.s.l. We included Inter-Andean valleys (those that separate the two parallel mountain chains from south of Colombia to northern Peru (Josse et al., 2011), Andean foothills and sub Andean regions but excluded the mountain chains of "Sierra de Córdoba" (Argentina) and "Sierra costera" (Chile). Studies in large catchments were included if at least half of the area upstream of the gauging station was at $>600$ m.a.s.l. We also examined publications presenting data from studies on forestation e.g., plantation forests, natural forest regrowth, natural regeneration and secondary succession. Regarding criteria (ii), we also included studies comparing native forests with other types of land use (Fig. 1), as they provide insights into the state of reference of hydrological services provided by forests, to which forest restoration can be compared (Bullock et al., 2011). Eight land use types were identified (Fig. 1).

Regarding criteria (iii), we included studies assessing variables related to water supply, hydrological regulation, control of water erosion, or mitigation of slope instability, at either the plot or catchment scale (Fig. 3). Conceptually, variables at the catchment scale can be viewed as "service indicators" whereas the plot scale variable are "process indicators". Service indicators are directly linked to an ecosystem service and can be interpreted in term 
of human well being. By contrast, process indicators are linked to different services with possible opposite impact (for example, soil water infiltration and storage can increase low flow production but can decrease slope stability). We included only studies reporting field measurements or model predictions that were calibrated or validated with field observations. Soil-related variables referred to sheet, rill and gully erosion, i.e., visible erosion marks or sediment generation by water erosion, as well as occurrence of shallow and non-seismic induced landslides in a catchment. Water-related variables included low or peak flows in catchments and infiltration or runoff in plots. In addition, soil organic matter content (SOM) was included as a variable of interest because it is related to soil water storage, soil erodibility and structure (Harden et al., 2018).

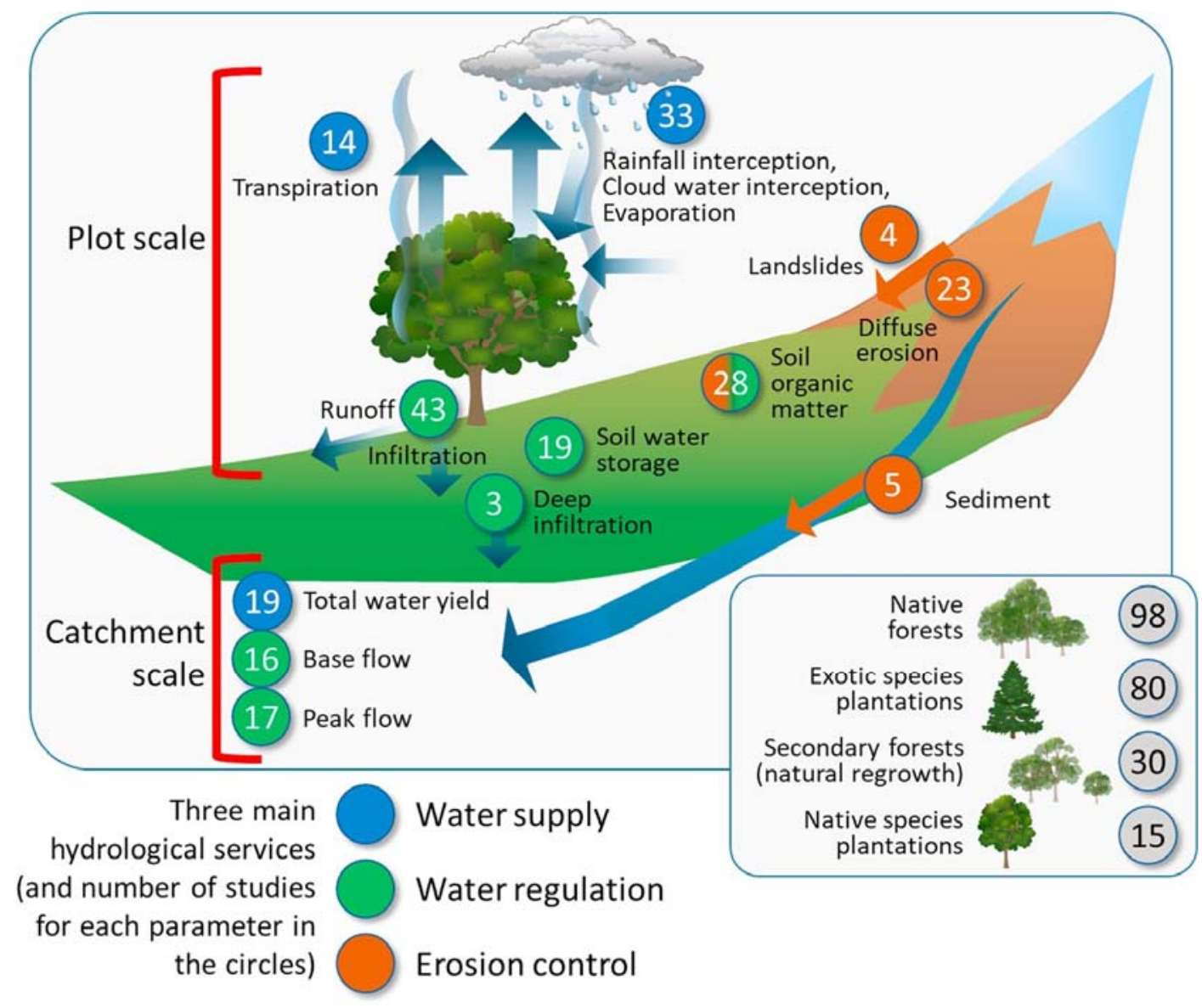

Fig. 3. Simplified hydrological cycle, soil and water variables considered in this review, and numbers of studies (in blue, green or orange circle according to the hydrological service) included for each variable and forest type.

\subsection{Assessment of sites as representative of the Andean mountain}

We assessed whether the selected studies were representative of the Andes in terms of spatial distribution, climate and soils. We mapped the extent of the Andean mountain, 
within the applied elevational belt between $600 \mathrm{~m}$ and the treeline. Treeline is difficult to establish in Andean regions (Sarmiento and Frolich, 2002) and we used the thermal treeline defined as the altitude where the mean annual temperature is near $7^{\circ} \mathrm{C}$. This definition is robust at global scale and allows to map consistently the treeline across the Andes (Körner and Paulsen, 2004). We compared the distribution of annual precipitations, temperatures, and soil type between the Andean mountain (above $600 \mathrm{~m}$ and under treeline) and the studies resulting from our literature search. For this, we used spatial climate data from WorldClim at 30 arc sec resolution (Trabucco and Zomer, 2009), elevation data from NASA Shuttle Radar Topographic Mission (90 m resolution, resampled to the WorldClim resolution) (Jarvis et al., 2008), and a map of soil types (Gardi et al., 2015). We noted the geographic coordinates of the sites reported in the studies or, if unavailable, used the site descriptions and Google Earth to find coordinates.

Studies were heterogeneously distributed in space (Fig. 4), with most studies in the northern Andes (Ecuador and Colombia, supplementary materials SM4) and northern Andean Patagonia. Therefore, the cloud montane forests and páramo ecosystems of northern Andes were more represented than the puna ecosystems of the central Andes (Josse et al., 2011). Dry areas of the Andes with a mean annual precipitation between $500 \mathrm{~mm}$ and $750 \mathrm{~mm}$ were underrepresented, although they would be suitable for planting dry-forest species (supplementary materials SM5). The most common soils under study were Andisols, i.e. soils from volcanic origin. 


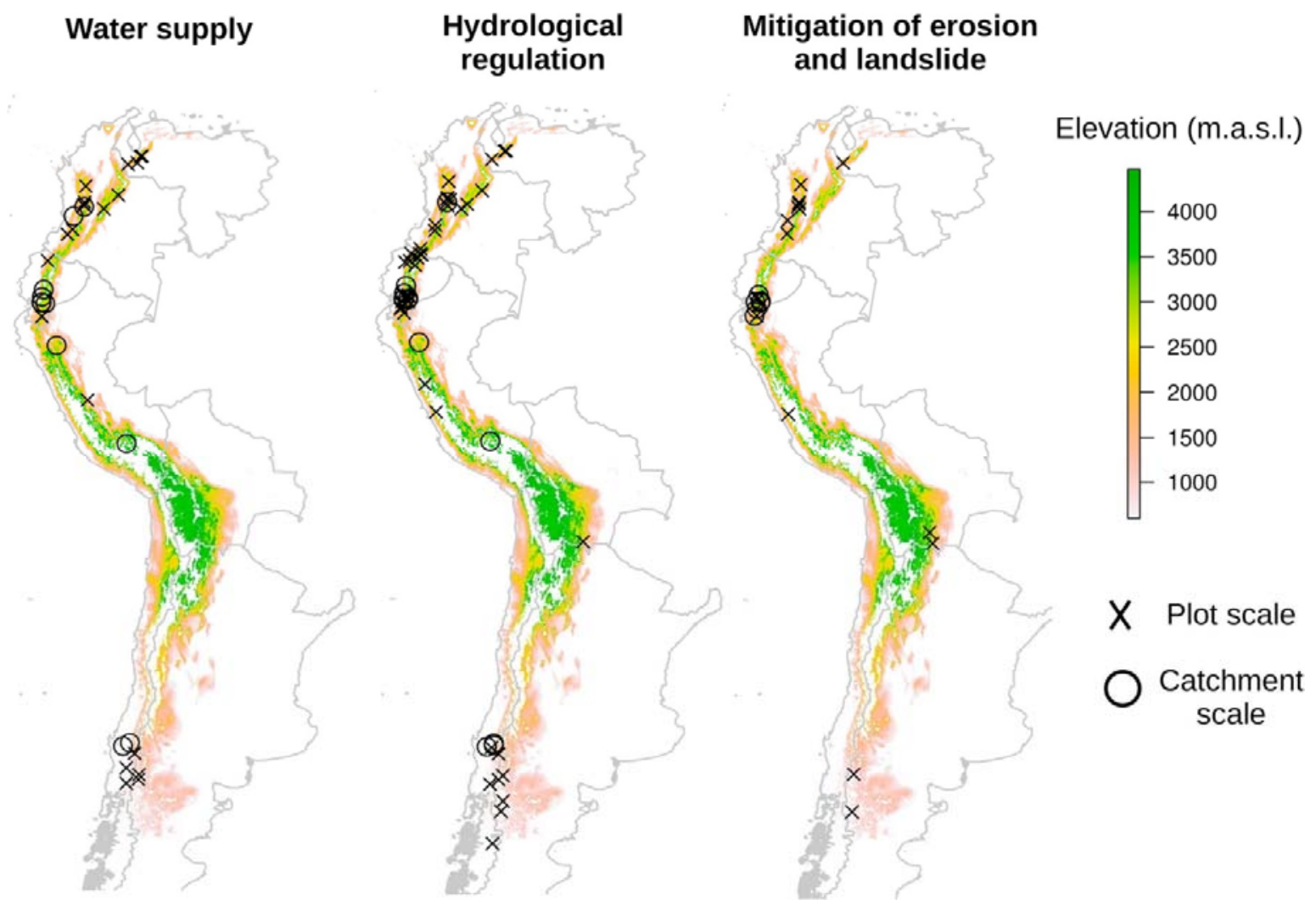

Fig. 4. Location of field sites with data that were analysed from plot scale (cross) and catchment scale (circle) studies in the literature search. Three elevation maps of the Andean cordillera are shown, each one corresponding to a different set of services: (i) water supply, (ii) hydrological regulation and (iii) mitigation of erosion and landslides. Only elevations between $600 \mathrm{~m}$ a.s.l. and the treeline are shown (see colour legend).

\subsection{Data extraction}

We extracted relevant data from the text, tables, supplementary materials, and figures (with the graph digitizers "engauge-digitizer" and "G3Data Graph Analyser"), and contacted authors if clarification or permissions were required. For each study, we described changes in land use (using the classification in Fig. 1) and other potential explanatory variables that could determine the impacts of forestation on hydrological services (Table 1). 
Table 1. Potential explanatory variables considered in the review ( $C=$ catchment, $P=$ plot $)$.

\begin{tabular}{|c|c|c|}
\hline Categories & Scale & Potential explanatory variables \\
\hline Climatic & $P, C$ & $\begin{array}{l}\text { Precipitation measured in the site, Mean annual climate } \\
\text { parameters extracted from the WorldClim dataset (precipitation, } \\
\text { temperature and evapotranspiration) }\end{array}$ \\
\hline Soil & $P, C$ & Soil type, Texture \\
\hline & $\mathrm{P}, \mathrm{C}$ & Altitude, Mean slope gradient \\
\hline spatial & C & Spatial extent \\
\hline Land-use history & $\mathrm{P}, \mathrm{C}$ & Previous land use, time since land use change \\
\hline $\begin{array}{l}\text { Land-use } \\
\text { management }\end{array}$ & $\mathrm{P}, \mathrm{C}$ & $\begin{array}{l}\text { Species, Density index (an ordinal variable estimated from Leaf } \\
\text { Area Index, LAI, or Basal Area, BA, using the following formula: } \\
\text { Density = } 1 \text { if } \mathrm{LAI}<3 \text { or BA }<25 \mathrm{~m}^{2} / \mathrm{ha} \text {, Density }=2 \text { if } 3<\mathrm{LAI}<6 \\
\text { or } 25<\mathrm{BA}<50 \mathrm{~m}^{2} / \mathrm{ha} \text {, Density }=3 \text { if } 6<\mathrm{LAI}<9 \text { or } \\
50<\mathrm{BA}<75 \mathrm{~m}^{2} / \mathrm{ha} \text {, and Density }=4 \text { if } \mathrm{LAI}>9 \text { or } \mathrm{BA}>75 \mathrm{~m}^{2} / \mathrm{ha} \text { ) }\end{array}$ \\
\hline & C & Distribution of land use types within the catchment area (\%) \\
\hline Methodological & $\mathrm{P}, \mathrm{C}$ & Method used, Monitoring period, Sampling resolution \\
\hline Degraded soil & $\mathrm{P}, \mathrm{C}$ & $\begin{array}{l}\text { Categorical variable ( } 1 \text { = explicit report of soil degradation ; } \\
0=\text { no report), Reports included severely eroded soil, bare soil, } \\
\text { compacted soil, recently burnt soil, and depleted soil }\end{array}$ \\
\hline
\end{tabular}

\subsection{Data synthesis}

We applied four data synthesis methods depending on the data available for each water or soil variable (Table 1). First, we used meta-analysis, the most rigorous data synthesis method (Valentine et al., 2010), when we had sufficient data for comparisons between interventions and controls (e.g., forested and non-forested land use), with sufficient statistical information (i.e., sample sizes, means, and standard deviation). This best case scenario was applied to only two variables (plot-scale infiltration and soil organic matter). The statistical method for the meta-analysis relied on mixed linear models, which are recommended for unconditional inference about a larger set of studies of which our selected studies are assumed to be a random sample (Viechtbauer, 2010, Zuur, 2009). We used a random effect to take into account dependency with regard to sampling errors at the study level, e.g. methods or spatial correlations. We used the general model:

$$
\theta_{i}=\beta_{0}+\Sigma \beta_{p} \cdot L U_{i, p}+\Sigma \beta_{q} \cdot P E V_{i, q}+u_{i}
$$

where $\theta_{i}$ is the effect size (comparison of the soil or water variable between intervention and control) of the $i$-th study, $L U_{i, p}$ is the $p$-th land use types comparison, $P E V_{i, q}$ 
is the q-th explanatory variable (categorical or covariate) of the $\mathrm{i}$-th study. The random effect $u_{i} \sim N\left(0, T^{2}\right)$ and $\beta_{0}, \beta_{p}, \beta_{q}$ are parameters estimated by the model. The contribution of each study was weighted according to the precision of their estimates (inverse variance weight), as is normally performed in meta-analyses. The entire variance-covariance matrix was computed to account for the dependency of sampling errors in studies when forestation was compared with more than one land use (e.g. contrasted with grassland and native forest). Rpackages Ime4 and metafor were used for linear mixed models and true meta-analysis respectively (Bates et al., 2007, Viechtbauer, 2010). Models and variables were selected according to the Bayesian information criteria (BIC) and t-test. We also used the omnibus test in our meta-analysis as a global test for including explanatory variables (Viechtbauer, 2010).

We applied meta-regressions when meta-analyses were not possible because standard deviations were not given, for any of the three variables: plot-scale rainfall interception, runoff and soil water storage. Since these variables were confined between 0 and 100, e.g. rainfall interception, surface runoff and soil water storage, we used a generalized linear mixed model framework (package Ime4) with a logit link function and a binomial distribution of the response variable (Zuur, 2009). In contrast to the meta-analysis, we did not weight the studies with the square root of the sample size as a precision weight, since large samples generally corresponded to studies with limited spatial coverage of the water collecting devices (rain gauges or rainfall-runoff plots), which actually did not increase the overall precision. However, we weighted observations based on their temporal resolution (storm event or week) as the ratio of bulk rainfall of each event over the mean annual rainfall, so as not to give too much weight to individual events compared to cumulative annual sampling. Information criteria BIC and t-tests were used for inclusion/exclusion of variables in the quantitative analysis. Maximum likelihood was used to compare models with different numbers of variables. Confidence interval and envelope were calculated with a bootstrap method (Zuur, 2009).

When diverse measurement methods and spatio-temporal scales impeded comparisons with statistical techniques, as was the case for several variables related to water erosion, we used a counting approach that focused on the direction of the impact of forestation and its statistical significance (i.e., counting only significant impacts) rather than its magnitude. The counting approach was not a vote-counting approach stricto sensu with statistical inference (Cooper and Hedges, 1994). Significant impacts (with significance level $0.05)$, either positive or negative, were counted and related to the total number of studies.

If none of the above data synthesis methods were possible because of data scarcity or heterogeneity, we reported findings qualitatively. This was the case for several variables at the catchment scale (e.g., landslides, low and peak flows) and the plot scale (e.g., transpiration, cloud water interception and deep infiltration). 


\subsection{Study quality and sensitivity analysis}

High quality studies should contribute more to evidence building than poor quality studies. We assessed the quality of a study by its reliability, i.e. the extent to which its design minimized susceptibility to bias. We analyzed our data using all studies and tested the robustness of the results by redoing the analyses with a "robust set" containing only the best quality studies (Higgins and Green, 2011). For assessing reliability, we considered the quality of the comparison between forestation and other land use types (Table 2) and the measurement techniques. For all data synthesis methods except the meta-regressions, best quality studies were those that clearly showed that control and intervention were assessed in similar or only slightly different biophysical site conditions, and that measurement techniques were those following the best practices used in the domain. In addition, for analyses of relative interception and runoff, we considered that best quality studies were those that sampled both the input and the output water (bulk rainfall and throughfall for interception studies and throughfall and surface runoff for runoff studies). Interception studies should have measured throughfall and bulk rainfall randomly with several rain gauges. In many studies, throughfall was measured at several places within a forest stand but bulk rainfall was usually measured at one single point only, despite rainfall spatial variability and the difficulty in measuring bulk rainfall near forest (Crockford and Richardson, 2000). Lack of stemflow measurement was not considered sufficient for rejecting the study, as the contribution of stemflow was often negligible (supplementary materials SM6, Van Stan and Gordon, 2018). Runoff studies should include data where runoff was measured in several plots and, if canopy cover existed, throughfall should have been measured with several randomly placed rain gauges. 
Table 2. Variables assessed in the selected studies, related ecosystem services, scales and data synthesis method used in the review $(C=$ catchment, $P=$ plot $)$.

\begin{tabular}{|c|c|c|c|c|c|}
\hline \multicolumn{2}{|c|}{ Ecosystem services } & \multirow{3}{*}{$\begin{array}{l}\text { Impact of forest on } \\
\text { service } \\
\text { Reducing water } \\
\text { erosion of soils } \\
\text { through soil } \\
\text { improvement or } \\
\text { protective vegetation } \\
\text { cover }\end{array}$} & \multirow{2}{*}{$\begin{array}{l}\text { Scale } \\
\text { C }\end{array}$} & \multirow{2}{*}{$\begin{array}{l}\text { Variable } \\
\text { Occurrence and magnitude of visible WATER } \\
\text { EROSION FEATURES, i.e. wearing away and } \\
\text { transport of soil by running water such as } \\
\text { sheet erosion, rills and gullies }\end{array}$} & \multirow{2}{*}{$\begin{array}{l}\text { Data synthesis } \\
\begin{array}{l}\text { Counting } \\
\text { approach }\end{array}\end{array}$} \\
\hline $\begin{array}{l}\text { Mitigation of } \\
\text { soil erosion } \\
\text { and landslide }\end{array}$ & $\begin{array}{l}\text { Erosion } \\
\text { control }\end{array}$ & & & & \\
\hline & & & $\mathrm{P}$ & $\begin{array}{l}\text { WATER EROSION PROXIES: soil aggregate } \\
\text { stability } 1 \text {, soil organic matter, rainfall } \\
\text { erosivity?2, sediment downhill }\end{array}$ & $\begin{array}{l}\text { Counting } \\
\text { approach }\end{array}$ \\
\hline & $\begin{array}{l}\text { Mitigation of } \\
\text { landslide }\end{array}$ & $\begin{array}{l}\text { Stabilizing soils and } \\
\text { reducing shallow } \\
\text { landslides }\end{array}$ & $\mathrm{C}$ & Occurrence and magnitude of LANDSLIDES 3 & $\begin{array}{l}\text { Qualitative } \\
\text { synthesis }\end{array}$ \\
\hline & $\begin{array}{l}\text { Regulation of } \\
\text { water } \\
\text { turbidity }\end{array}$ & $\begin{array}{l}\text { Reducing sediment } \\
\text { load (reducing } \\
\text { production and } \\
\text { transport, improving } \\
\text { capture and storage); } \\
\text { improving water } \\
\text { quality }\end{array}$ & $\mathrm{C}$ & $\begin{array}{l}\text { SEDIMENT YIELD: Total sediment outflow } \\
\text { from a drainage basin or past a given open } \\
\text { channel location in a specified period of } \\
\text { time, comprising the sum of the bed load } \\
\text { and the suspended load, expressed as } \\
\text { weight per unit time } 4\end{array}$ & $\begin{array}{l}\text { Counting } \\
\text { approach }\end{array}$ \\
\hline \multirow[t]{4}{*}{ Water supply } & & $\begin{array}{l}\text { Preserving the supply } \\
\text { of surface and } \\
\text { groundwater }\end{array}$ & $\mathrm{C}$ & $\begin{array}{l}\text { WATER YIELD: Quantity of water which can } \\
\text { be collected for a specified use from surface } \\
\text { or groundwater sources in a basin during a } \\
\text { given time interval } 4\end{array}$ & $\begin{array}{l}\text { Qualitative } \\
\text { synthesis }\end{array}$ \\
\hline & & & $\mathrm{P}$ & $\begin{array}{l}\text { RAINFALL INTERCEPTION: Amount of rainfall } \\
\text { that does not reach the ground and } \\
\text { eventually evaporates, can be considered as } \\
\text { a loss for the catchment water yield }\end{array}$ & $\begin{array}{l}\text { Meta- } \\
\text { regression }\end{array}$ \\
\hline & & & & $\begin{array}{l}\text { CLOUD WATER INTERCEPTION: Cloud water } \\
\text { refers to the entire size spectrum of fog, } \\
\text { drizzle and rain present in a cloud. } .5 \text { Its } \\
\text { interception by canopy can be considered a } \\
\text { gain for the catchment water yield }\end{array}$ & $\begin{array}{l}\text { Qualitative } \\
\text { synthesis }\end{array}$ \\
\hline & & & & $\begin{array}{l}\text { TRANSPIRATION: Water movement through } \\
\text { a plant and its evaporation from aerial parts }\end{array}$ & $\begin{array}{l}\text { Qualitative } \\
\text { synthesis }\end{array}$ \\
\hline \multirow[t]{2}{*}{$\begin{array}{l}\text { Hydrological } \\
\text { regulation }\end{array}$} & $\begin{array}{l}\text { Low flow } \\
\text { conservation }\end{array}$ & $\begin{array}{l}\text { Maintaining } \\
\text { minimum flow in } \\
\text { streams and rivers } \\
\text { during the dry } \\
\text { periods of the year } \\
\text { though storage (in } \\
\text { soil and aquifers) and } \\
\text { release during dry } \\
\text { seasons; reducing } \\
\text { water scarcity and } \\
\text { drought impacts }\end{array}$ & $\mathrm{C}$ & $\begin{array}{l}\text { LOW FLOW: Flow of water in a stream } \\
\text { during prolonged dry weather. Low flow are } \\
\text { derived from groundwater discharge or } \\
\text { surface discharge from lakes, marshes, or } \\
\text { melting glaciers } 4\end{array}$ & $\begin{array}{l}\text { Qualitative } \\
\text { synthesis }\end{array}$ \\
\hline & $\begin{array}{l}\text { Flood } \\
\text { reduction }\end{array}$ & $\begin{array}{l}\text { Reducing peak flows } \\
\text { in streams and rivers } \\
\text { during rainfall events; } \\
\text { reducing the } \\
\text { magnitude and } \\
\text { frequency of floods }\end{array}$ & $\mathrm{C}$ & $\begin{array}{l}\text { PEAK FLOW: Maximum instantaneous } \\
\text { discharge of a given stream, shown by the } \\
\text { discharge hydrograph, for a specific event }{ }^{4}\end{array}$ & $\begin{array}{l}\text { Qualitative } \\
\text { synthesis }\end{array}$ \\
\hline
\end{tabular}




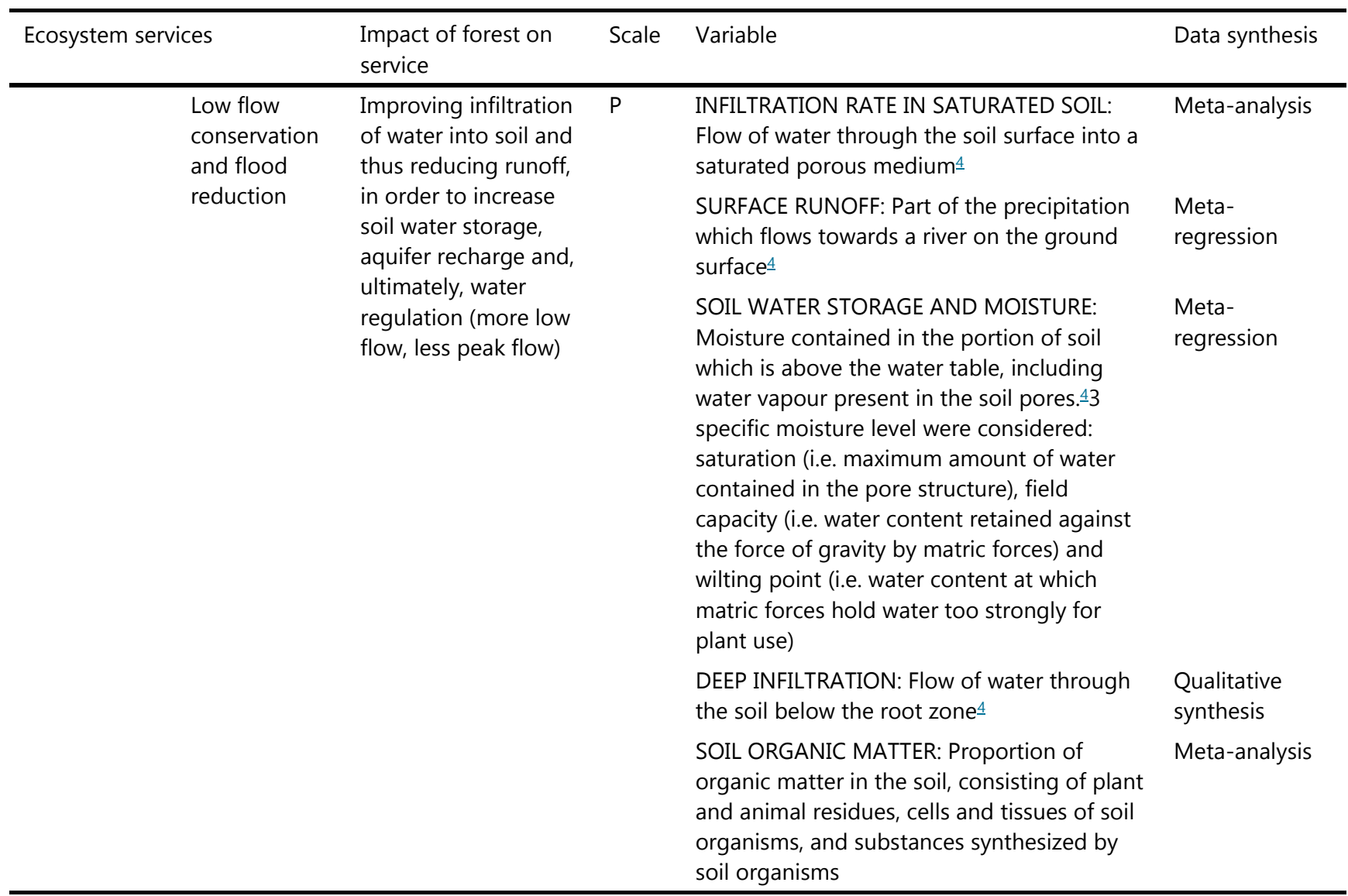

1: Soil aggregate stability is a measure of the ability of soil aggregates to resist degradation when exposed to external forces such as water erosion (USDA Natural Resources Conservation Service, 1996).

2: Rainfall erosivity represents the erosive force of rainfall and combines the effect of the duration, magnitude and kinetic energy of raindrop's impact of a rainfall event (Panagos et al., 2015).

3: Downward and outward movement of slope- forming materials composed of natural rocks, soil, artificial fill, or combinations of these materials (Stokes et al., 2014).

4: World Meteorological Organization (2012).

5: Bruijnzeel et al. (2010). 


\section{Results}

For each group of results, we indicate the levels of evidence and agreement, using three categories: Consensual (medium to high agreement among numerous studies including high quality studies), probable (medium to high agreement among few studies), controversial (low agreement among numerous studies) and gap knowledge (low agreement or disagreement among few studies).

\subsection{Impact of forestation on soil erosion and landslides}

\subsubsection{Consensual: forestation decreases erosion to almost natural erosion rates}

Many studies applying different methods at plot and catchment scales converge to show that forestation reduced water erosion of soils, whereas overgrazing and cropping systems increased surface runoff and water erosion (Table 3, Table SM1). Surface vegetation cover was found to be key in protecting the soil surface from water erosion both at plot scale and catchment scale (Molina et al., 2007a, Vanacker et al., 2007). A statistical analysis of 37 micro-catchments in the Inter-Andean valley of south Ecuador showed that the surface vegetation cover exerts a first order control on sediment yield with $57 \%$ of the observed variance in sediment yield explained by the surface vegetation cover (Molina et al., 2007a). Sediment production decreased exponentially with surface vegetation cover so that a small increase in cover on bare land resulted in a strong decrease in erosion. Accordingly, native forest and undisturbed or extensively grazed grassland had very low erosion rates even on steep slopes (less than $1 \mathrm{t} / \mathrm{ha} / \mathrm{yr}$ ), while agriculture and degraded land had higher erosion rates by one or two orders of magnitude (Vanacker et al., 2014, Vanacker et al., 2007). Although pasture produced more superficial runoff than cultivated land, sediment rate was three times lower (Harden, 1996). With their intermediate surface cover, exotic tree plantations and natural regeneration slightly increased erosion rates compared with grassland but hugely decreased erosion rates compared with degraded soils (Vanacker et al., 2007). The particular capacity of Eucalyptus spp. plantation to mitigate water erosion has sometimes been questioned (Harden, 1992, Inbar and Llerena, 2000). Nevertheless, Eucalyptus spp. planted on degraded soils reduced water erosion (Molina et al., 2009, Molina et al., 2012, Vanacker et al., 2007). On the contrary, Pinus spp. plantations consistently reduced water erosion on degraded soils in reviewed studies which may be due to the protection of the litter layer (Manna et al., 2016). Investigations using radionuclide tracers showed that the sediment production of exotic tree plantations can be as low as in undisturbed land use ( $1 \mathrm{t} / \mathrm{ha} / \mathrm{yr}$ ) (Vanacker et al., 2007, Vanacker et al., 2014). For a given land cover configuration, the spatial organization of forest and other land use types within the catchment strongly controls the sediment export in degraded catchments. Vegetation restoration by tree plantation or forest natural regeneration in gully channels effectively retained eroded sediment in the gully bed and reduced sediment export from degraded catchments (Molina et al., 2009, Molina Verdugo et al., 2009). 
Table 3. Distribution of comparisons of water erosion of soils at plot and catchment scales according to whether a forested land use decreased, increased or did not influence erosion rates compared with non-forested land use.

\begin{tabular}{lllll}
\hline Forested land use & $\mathrm{N}$ comparisons (N studies) & Decrease & No effect & Increase \\
\hline Native forest & $10(6)$ & $60 \%$ & $40 \%$ & 0 \\
Natural regeneration & $10(7)$ & $50 \%$ & $40 \%$ & $10 \%$ \\
Exotic tree plantation & $17(10)$ & $59 \%$ & $18 \%$ & $23 \%$ \\
Native tree plantation & $2(1)$ & $50 \%$ & $50 \%$ & 0 \\
\hline
\end{tabular}

\subsubsection{Gap knowledge: impact of forestation on landslides}

Field observations and slope stability analysis provide evidence that deforestation increases the occurrence of shallow landslides (Guns and Vanacker, 2013, Muenchow et al., 2012). In contrast, the impact of forestation on slope stability has received very limited attention, and has been investigated mostly through modeling (Bathurst et al., 2010b) or with indicators of ecosystem restoration after a landslide (Calle et al., 2013). As a consequence, the potential effects of forestation on slope stability should be considered with care, as it has even been shown in the Ecuadorian Andes that the weight of soil and vegetation can destabilise steep slopes ( $>38^{\circ}$ ) (Vorpahl et al., 2013).

\subsection{Impact of forestation on water supply}

\subsubsection{Consensual: exotic tree plantations decrease downstream water yield in most regions}

The plantation of exotic tree species consistently decreased water yield regardless of the catchment size and the method used (Table SM2). In a quantitative synthesis of the results from four pairs of small high Andean catchments (Ochoa-Tocachi et al., 2018, OchoaTocachi et al., 2016a), exotic tree plantations produced the lowest water yield, while natural grasslands produced the highest yield and native forest had an intermediary water yield. This synthesis showed that an expansion of fast-growing exotic plantations over $1 \%$ of the catchment area resulted in a decrease of $0.4 \%$ water yield if they replaced natural grasslands and $0.2 \%$ if they replaced grazed grasslands (a catchment covered by plantation would thus result in a $40 \%$ decrease in water yield if they replaced natural grasslands and $20 \%$ if they replaced grazed grasslands). Two catchment pairs not included in this synthesis showed similar hydrological responses. In time-series analyses of two Chilean meso-scale catchments $(100 \mathrm{~km} 2<$ area $<10000 \mathrm{~km} 2)$, the area of fast-growing exotic plantations exceeded the area 
of deforestation, with a net forest area increase by $1 \%$ resulting in a reduction of the water yield by $0.11-1.2 \%$ (Iroumé and Palacios, 2013, Stehr et al., 2008, Stehr et al., 2010). However, contrasted responses of two Ecuadorian meso-scale catchments were difficult to attribute to specific land-use changes as deforestation and forestation occurred simultaneously and in the same proportion (Molina et al., 2015, Molina et al., 2012).

\subsubsection{Consensual: forest canopy intercepts substantial amount of water}

Plot scale studies of rainfall interception confirmed to a certain extent how forest cover caused reduction in water yields at the catchment scale. Our meta-regression showed that the mean annual relative interception in tree plantations, native forests and agroforestry was $25 \%$ of bulk rainfall ( $\mathrm{CI}$ at $95 \%$ : $19-33 \%$ ). Plantation forests had a relative interception that was similar to native forest or agroforests. Our meta-regression did not detect a significant effect of tree density on the relative interception neither did studies with data at a high temporal resolution.

Very few studies compared the interception between tree cover and non-tree cover in a robust way, because throughfall under canopy cover was usually measured above the grass height, which neglected the potentially important rainfall interception of grassland (Ataroff and Rada, 2000, Ochoa-Sánchez et al., 2018, Peralta and Ataroff, 2005) (Table SM3).

As native forests and plantation canopies in dry regions intercepted slightly more rainfall than in less dry regions (Fig. 5), forestation can worsen water scarcity in dry regions. The sensitivity analysis on the robust data set confirmed these results. This is consistent with interception measurements at high temporal resolution of native forest and tree plantation where small rainfall events were largely intercepted and evaporated while heavy rainfall events were marginally affected by interception (Fleischbein et al., 2011, Huber and Trecaman, 2002, Licata et al., 2011). 


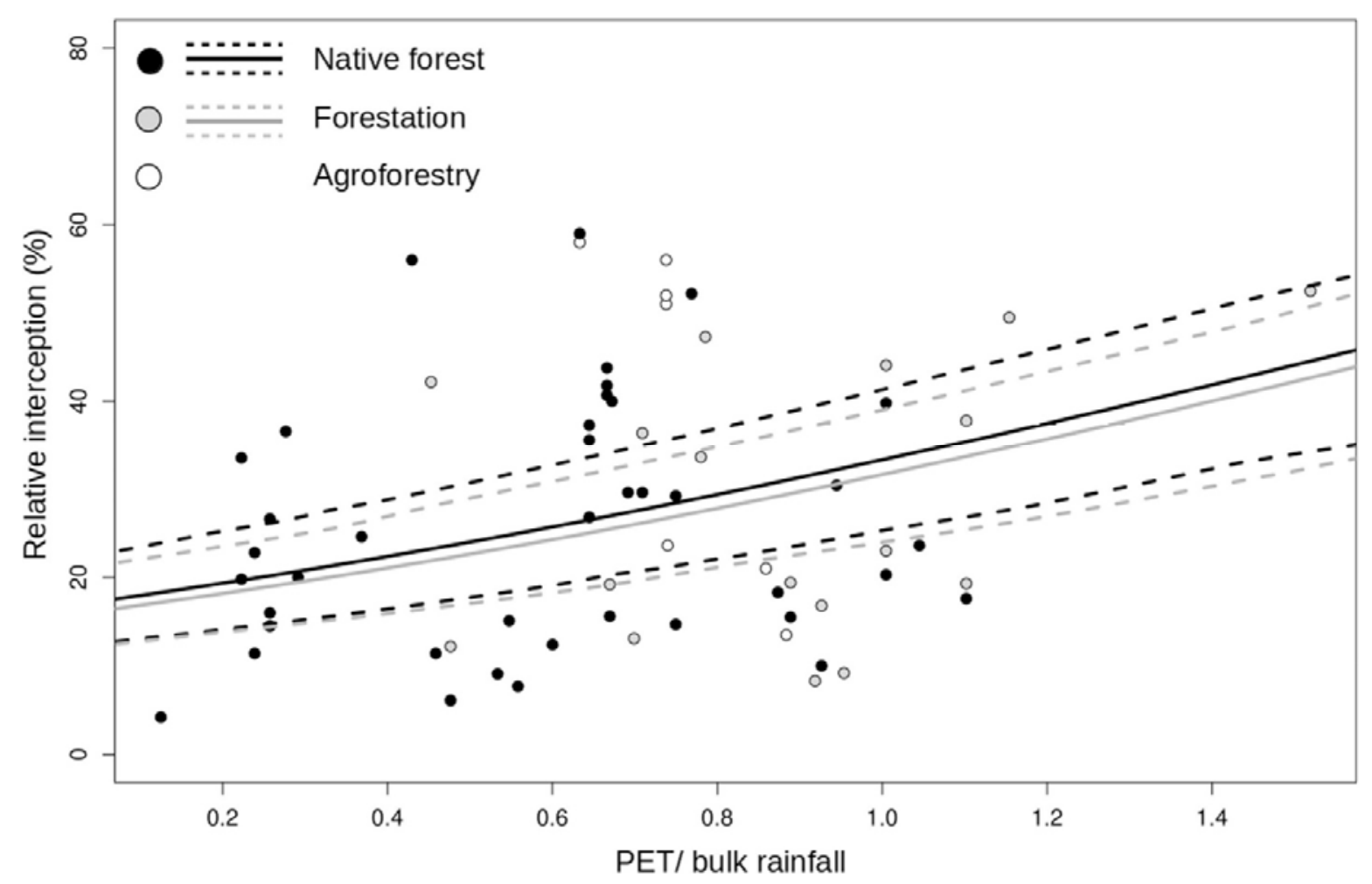

Fig. 5. Impact of climate and land use types on relative interception for all the studies. $x$-axis is the ratio of the annual potential evapotranspiration (PET) to annual bulk rainfall (see supplementary materials SM6). Native forests are represented by black dots (observation), solid line (model prediction of the mean) and dotted lines (confidence envelope at 95\%). Forestation is represented by gray dots (observation), solid line (model prediction of the mean) and dotted lines (confidence envelope at 95\%). Agroforestry is represented by white dots only (observation).

\subsubsection{Probable: exotic tree plantations increase transpiration losses in most regions}

Although forest transpiration is often pointed to as a major loss of water in forested catchments, it has been overlooked at the plot scale, except in some native tropical cloud montane forest and in northwest Patagonia (Gyenge et al., 2011 and Table SM4). In this latter region, plantations of exotic pine (Pinus ponderosa) or Douglas fir (Pseudotsuga menziesii) transpired more water (around $1 \mathrm{~mm} \cdot$ day-1) than native grassland and similar amounts or more water than native forest. In contrast to interception, there was a significant positive effect of stand density on transpiration, although differences in transpiration were not proportional to differences in leaf area (Gyenge et al., 2010, Gyenge et al., 2011).

Transpiration efficiency was lower in native forests than in plantations, which produced more wood or biomass per unit of water consumed (Gyenge et al., 2011). Nevertheless, transpiration rates and water use efficiency were highly variable among Patagonian native 
forest species and some native species had a similar water use efficiency to the exotic conifer species.

\subsubsection{Gap knowledge: impact of forestation in montane cloud ecosystems}

Montane cloud forest ecosystems deserve a special attention because forest immersion in a layer of clouds reduces transpiration and promotes cloud water interception, which can lead to a low tree water use and higher water yield compared to grassland (Molina et al., 2015, Sáenz et al., 2014). However, measuring the contribution of cloud-water and horizontal rain on interception and transpiration is complex and requires sophisticated instrumentation (passive and active fog gauge, wind speed, isotope tracers) and models (Bruijnzeel et al., 2010). In the reviewed studies using appropriate techniques, annual cloudwater interception was reportedly low in native cloud montane forest (less than $2 \%$ of vertical rainfall and with a maximum of 7.9\%) (Gonzalez, 2011, Mulligan et al., 2011) except for a study in Peru where cloud-water interception reached $22 \%$ of the annual rainfall (Gomez-Peralta et al., 2008). Repetitive fog immersion reduced the evaporative potential (Catchpole, 2012, Table SM4) which likely explained the low transpiration observed in native montane cloud forests (Ataroff and Rada, 2000, Fleischbein et al., 2006, Motzer et al., 2011). To our knowledge, no studies have measured the cloud water interception nor the canopy transpiration of regenerated forests or tree plantations with appropriate techniques.

\subsection{Impact of forestation on hydrological regulation}

\subsubsection{Consensual: exotic tree plantations on degraded soils improve infiltration rate}

Forestation on grazed grassland strongly increased the saturated infiltration rate by 8 times after 14-20 years and led to a partial recovery of the soil infiltration capacity of native forests. The saturated infiltration rate in forestation over grassland was three times lower than the rate in native forests, but this result was not significantly different (Fig. 6, Table SM5). All studies on forestation but two, dealt with exotic tree plantations. In páramo ecosystem, the saturated infiltration rate of a pine plantation was three times higher than the rate of an ungrazed grassland and in between the rates of two native forests (Quichimbo et al., 2012). Restricting the analysis to the most reliable studies gave a higher positive effect of forestation on saturated infiltration rate (see supplementary materials SM7 for a file drawer issue). Studies measuring rainfall intensity reported that intensities exceeded saturated infiltration rate more often in grassland than in forests, which led to less frequent surface runoff in the latter case (Hoyos, 2005, Zimmermann and Elsenbeer, 2009). 


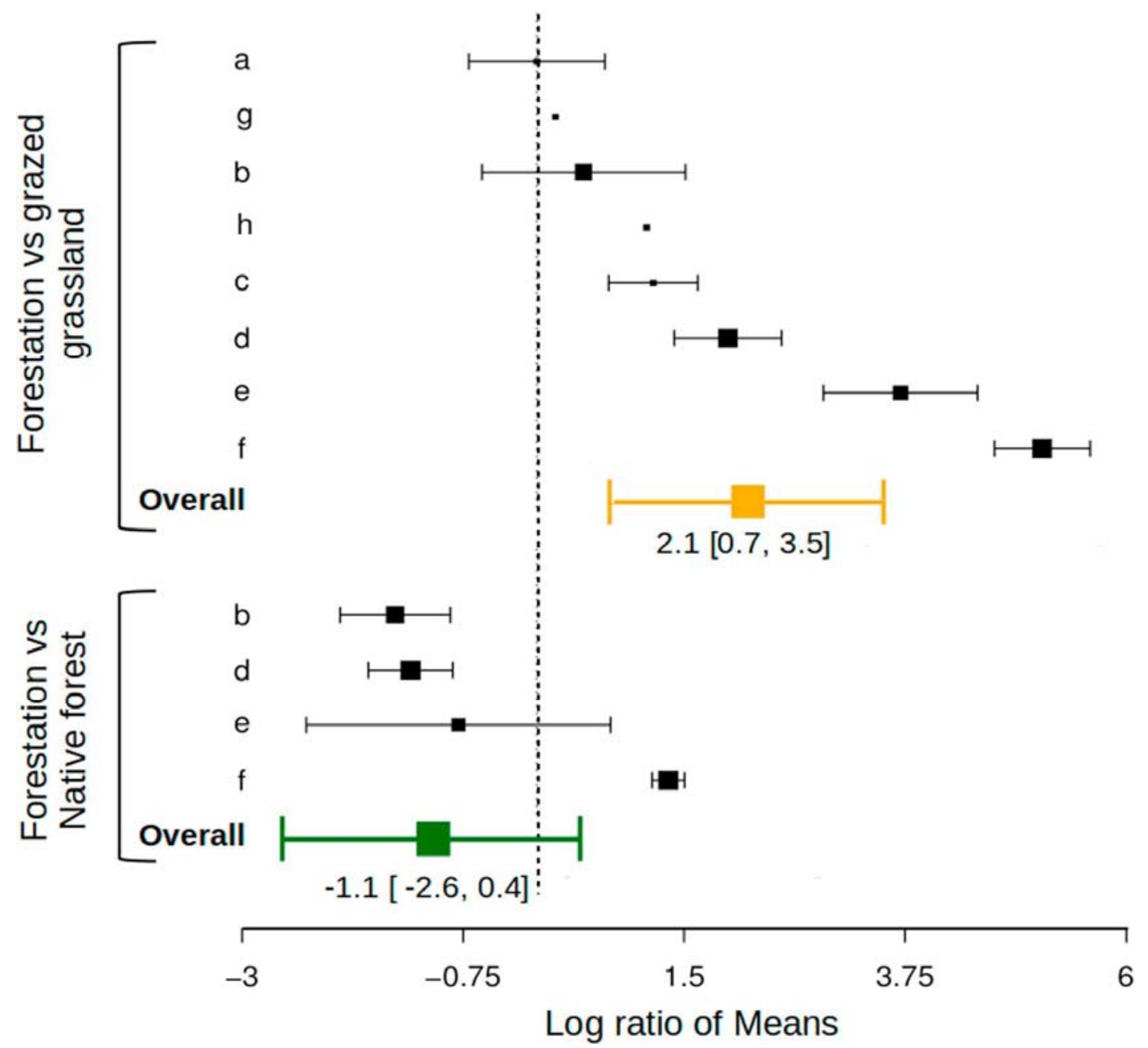

Fig. 6. Effect sizes of saturated infiltration rates (here expressed as log ratio of means of saturated infiltration rates). Squares show mean values for each study (the thicker the squares, the higher the study weights). Whiskers show the $95 \%$ confidence interval. The green error bar is the fixed effect for the comparison forestation versus native forest estimated on all the studies. The orange error bar is the fixed effect for the comparison forestation versus grazed grassland estimated on all the studies. The estimated mean [95\% confidence interval] is shown under the error bars. Letters in the left column refer to studies: $a=$ (Gonzalez Alfaro, 2015), b = (Moreno Vallejo, 2012), c = (Gaitán et al., 2016), $d=($ Sadeghian et al., 2001),$e=($ Hoyos, 2005), $f=($ Zimmermann, 2007), $g=($ Díaz Betancourt, 2008), $h=$ (Quichimbo et al., 2012). Studies $g$ and $h$ were not used for fitting the model.

\subsubsection{Consensual: native forests and exotic tree plantations decrease peak flow except during extreme rainfall events}

Field observation and modeling concluded that forest cover attenuated peak flows to a certain rainfall threshold: as storm intensity increased, the forest capacity to buffer floods decreased (Table SM2, Bathurst et al., 2010a, Bathurst et al., 2011a, Bathurst et al., 2011b, Bravo Martínez, 2015, García Olmos, 2007). Another study using sophisticated methods 
showed, however, that native forest and exotic tree plantation buffered peak flow even during the most intensive storms (Roa-García and Weiler, 2010). All studies agreed that peak flow generated by storm events with a return period of 10 years or shorter could be significantly reduced by forest cover. Exotic tree plantation may have a slightly lower capacity to buffer peak flow than native forests as native forests had slightly lower surface runoff and slightly higher soil water storage capacity than exotic tree plantations (Table 4, Fig. 5, Fig. 6, Fig. 8).

Table 4. Odds-ratio of land-use transition in studies of plot-scale runoff (all studies). CI 95\% is the confidence interval of the odds-ratio at $95 \%$ confidence level.

\begin{tabular}{|c|c|c|c|c|c|}
\hline \multicolumn{2}{|c|}{ Before forestation } & \multicolumn{2}{|c|}{ After forestation } & \multirow{2}{*}{$\begin{array}{l}\text { Estimate of } \\
\text { odds-ratio }\end{array}$} & \multirow[t]{2}{*}{ CI $95 \%$} \\
\hline $\begin{array}{l}\text { Land use } \\
\text { type }\end{array}$ & $\begin{array}{l}\text { Soil } \\
\text { degradation }\end{array}$ & $\begin{array}{l}\text { Type of } \\
\text { forestation }\end{array}$ & $\begin{array}{l}\text { Soil } \\
\text { degradation }\end{array}$ & & \\
\hline \multirow[t]{2}{*}{$\begin{array}{l}\text { Non forested } \\
\text { land }\end{array}$} & No & $\begin{array}{l}\text { Exotic tree } \\
\text { plantation }\end{array}$ & No & 1.27 & $\begin{array}{l}{[1.1-} \\
1.5]\end{array}$ \\
\hline & & $\begin{array}{l}\text { Natural } \\
\text { regeneration }\end{array}$ & No & 1.19 & $\begin{array}{l}{[0.89-} \\
1.6]\end{array}$ \\
\hline \multirow[t]{3}{*}{$\begin{array}{l}\text { Non forested } \\
\text { land }\end{array}$} & Yes & $\begin{array}{l}\text { Exotic tree } \\
\text { plantation }\end{array}$ & No & 0.47 & $\begin{array}{l}{[0.19-} \\
1.2]\end{array}$ \\
\hline & & $\begin{array}{l}\text { Natural } \\
\text { regeneration }\end{array}$ & No & 0.44 & $\begin{array}{l}{[0.16-} \\
1.2]\end{array}$ \\
\hline & & $\begin{array}{l}\text { Natural } \\
\text { regeneration }\end{array}$ & Yes & 1.19 & $\begin{array}{l}{[0.89-} \\
1.6]\end{array}$ \\
\hline \multirow[t]{2}{*}{ Native forest } & No & $\begin{array}{l}\text { Exotic tree } \\
\text { plantation }\end{array}$ & No & 2.37 & $\begin{array}{l}{[2.0-} \\
2.8]\end{array}$ \\
\hline & & $\begin{array}{l}\text { Natural } \\
\text { regeneration }\end{array}$ & No & 2.22 & $\begin{array}{l}{[1.5-} \\
3.3]\end{array}$ \\
\hline
\end{tabular}

\subsubsection{Consensual: exotic tree plantations reduce low flow except in degraded lands}

The synthesis of small paired high Andean catchments clearly showed the negative effects of exotic tree plantations on low flows: their expansion over $1 \%$ of the catchment area led to a decrease of $0.4 \%$ of low flow in natural grasslands and $0.15 \%$ on grazed grasslands (Ochoa-Tocachi et al., 2018, Ochoa-Tocachi et al., 2016a, Ochoa-Tocachi et al., 2016b; Table SM2). Native forests produced the highest ratio of low flow to total flow compared to other land use types. They also provided as much low flow (in absolute values) as native grasslands 
and significantly more than grazed grasslands, although their overall water yield was lower than in native grasslands. Exotic species plantation on grazed grassland did not influence the ratio of low flow to total flow. In meso-scale catchments including inter-Andean ecosystems, the impact of exotic tree plantations on low flows was more variable. In an Ecuadorian interAndean catchment, the increase of low flow was attributed to deforestation and to plantations with Eucalyptus spp. on degraded lands (Molina et al., 2012).

\subsubsection{Consensual: exotic tree plantations decrease soil moisture}

Most field measurements revealed in situ soil moisture significantly lower for exotic tree plantation than other land use types including natural regeneration, at least during the dry season. In addition, exotic tree plantations consistently reached the wilting point during the monitoring period (Gyenge et al., 2009, Roa-García et al., 2011, Weigandt et al., 2011), while control land use not always did. Undisturbed páramo grassland had the highest soil moisture, even higher than native forest or plantation of native species (Harden, 2006, Harden et al., 2013). Native trees planted in agroforestry systems on degraded and semi-arid land rapidly increased soil moisture due to an increase in soil infiltration (Bastian and Gräfe, 1989).

Soil moisture depends not only on water balance but also on soil water storage capacity (supplementary materials SM8, Table SM6). Undisturbed native grassland had the highest water storage at saturation (75\%) and field capacity (60\%) compared with other types of land use, including forestry with water storage of about $65 \%$ at saturation and $43 \%$ at field capacity. However, water storage at saturation, field capacity and wilting point significantly increased with SOM (Fig. 7) and the impact of land use on soil water storage was very likely due to the impact of land use on SOM. Our data were mostly restricted to andisols and to a lesser extent, páramo ecosystems, known for their excellent water storage capacity. 


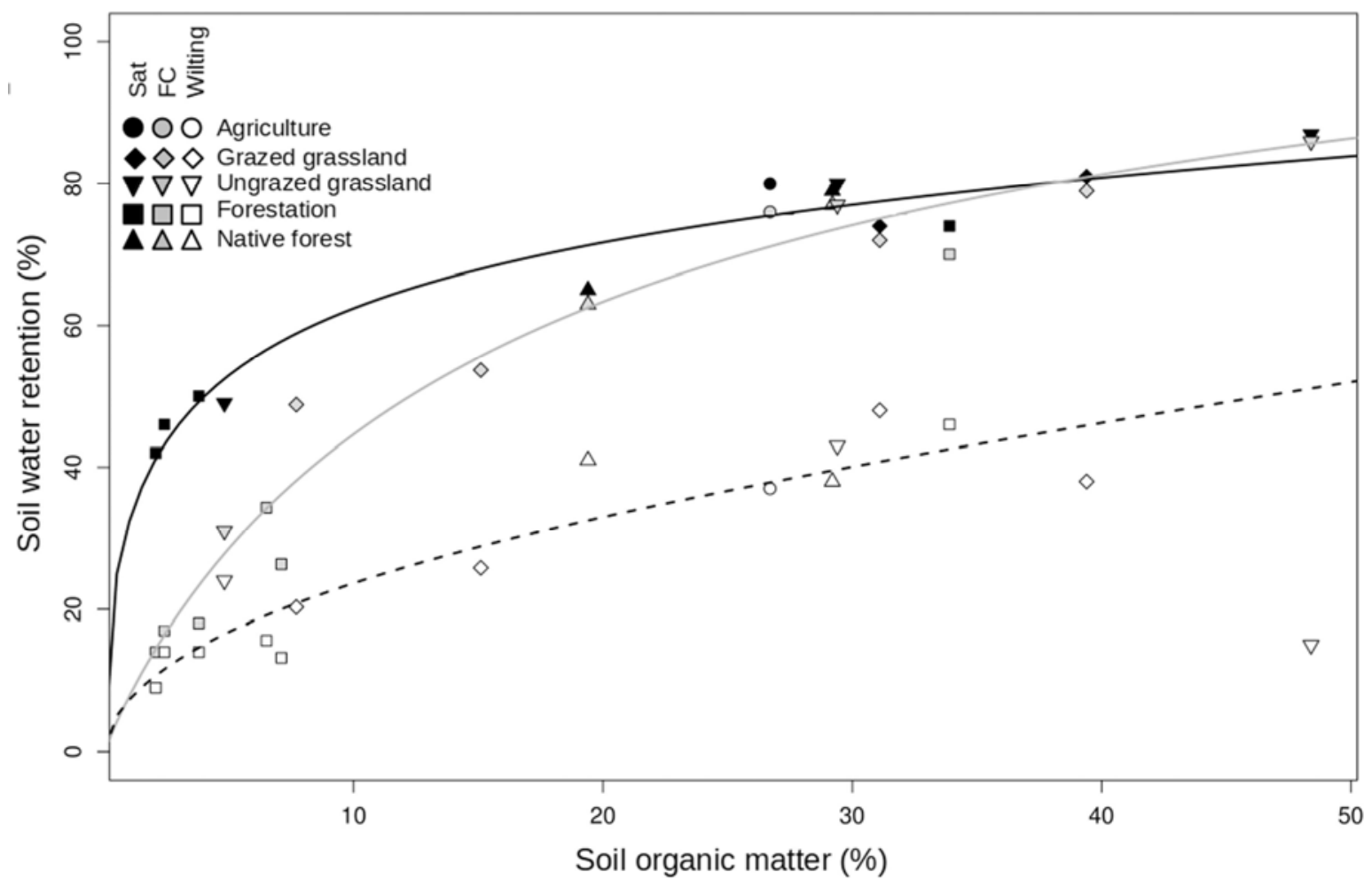

Fig. 7. Effect of soil organic matter on water storage at saturation (Sat, black solid line), field capacity (FC, gray solid line) and wilting point (Wilt, black dotted line) for different land uses (shapes) in the most reliable studies. The slopes of the three models were significantly different from 0 in the linear scale $(p<0.001)$.

\subsubsection{Probable: forestation on degraded soils decreases surface runoff}

Soil degradation represented an important driver of surface runoff in the metaregression (odds-ratio $=2.7$, see supplementary materials SM9, Table SM7). In degraded soils with low surface vegetation cover, the presence of smectites (clay minerals) in the soil made it very prone to sealing and crusting, thereby enhancing runoff generation (Molina et al., 2007b). An increase of surface vegetation cover over $50 \%$ resulted in a sharp decrease in surface runoff (Molina et al., 2007b). Importantly, authors did not report obvious signs of soil degradation in exotic tree plantations that were $>20$ years old, even though they had very often been planted on degraded soils or soils prone to degradation. Therefore, exotic tree plantations divided by 2 the surface runoff of degraded soils ( $p$.value $=0.06$ ) and appear as a potential way of reducing surface runoff on degraded soils (Table 3). In contrast, up to $97 \%$ of the sites classified as "natural regeneration" were affected by soil degradation with surface runoff similar to surface runoff before forestation. Several reviewed studies mentioned that (over)grazing occurred on abandoned land, which can hinder natural forest regrowth and soil recovery (Bastian and Gräfe, 1989, Harden, 1996, Molina et al., 2007b). However, when grazing was prohibited (or not indicated), natural regeneration generally succeeded in reducing surface runoff of degraded soils. 
In the absence of soil degradation, surface runoff was generally low in reviewed studies (around $2 \%$ of throughfall for annual measurements and $20 \%$ for measurement of a particularly intense event). Native forests generated less surface runoff than any other land use type (Table 4). On non-degraded soils, natural regeneration and agroforestry had similar surface runoff to agricultural land and grassland but tree plantation, mainly represented by exotic tree species, increased significantly runoff generation. When restricting model fitting to the most reliable studies, we also found a strong effect of exotic tree species (odds-ratio of exotic tree plantation compared to grassland and agricultural land $=5.8$ ). The increase in surface runoff may be explained by water repellency or hydrophobicity (created by the accumulation of organic compounds on or between soil particles) associated with exotic tree species as was the case of a plantation (Pinus patula and Cupressus lusitanica) in Colombia (Duque Zapata et al., 2004, Jaramillo Jaramillo and Vanegas Villa, 2007).

\subsubsection{Gap knowledge: impact of forestation on deep infiltration}

There was almost no information of the effects of forestation on deep infiltration and authors reported limited effects or no effect at all. Similar amounts of water infiltrated at a depth of $0.75 \mathrm{~m}$ in soil were reported for exotic plantations and native forest (García Olmos, 2007). An analysis with piezometers at a depth of $3.5 \mathrm{~m}$ showed no effect of a Pinus ponderosa plantation on groundwater recharge (Weigandt et al., 2011). Despite water repellency of topsoil under exotic coniferous plantations, a Cupressus lusitanica stand had a much larger amount of water infiltrated at $0.8 \mathrm{~m}$ depth than in native forests or Pinus patula plantations, probably due to the presence of macropores and increased preferential water flow to deeper horizons (León Peláez et al., 2010).

\subsection{Crosscutting issue: impact of forestation on soil organic matter}

The impacts of forestation on soil organic matter (SOM) are a cross-cutting issue as SOM likely to influences soil water storage capacity since we found a clear increase of soil water retention with SOM (Fig. 7), Soil aggregate stability also increased with higher levels of SOM, thus reducing soil erodibility in a natural regeneration of forest (Cerdà, 2000), and (to a smaller extent) infiltration, and runoff (Harden, 1996, Quichimbo et al., 2012).

\subsubsection{Consensual: forestation decreases soil organic matter compared to páramo grassland and native forests}

Forestation had lower SOM than native forests (standardised mean difference $=-1.4$, change in $\mathrm{SOM}=6.5 \%, \mathrm{p}=0.013$ ) and grasslands, although the difference was not significant (difference $=-0.5$, change in $\mathrm{SOM}=2 \%, \mathrm{p}=0.15$ ) (Figs. 8 and 9, supplementary materials SM10, Table SM8). Land use history was a better predictor of SOM change than forestation management, species, and age. In Ecuador, grazing had a large impact on SOM, not only in grassland but also in Pinus spp. plantations: differences between grazed and ungrazed 
plantations were greater than differences between ungrazed plantations and natural ecosystems (Hofstede et al., 2002). The dominant factor explaining changes in SOM following forest natural regeneration in pastures was pasture age: natural regeneration on grassland grazed for several decades generally led to an increase of soil carbon (de Koning et al., 2003). In mineral soils (SOM content <25\%), forestation increased SOM if the soil was originally poor in SOM but decreased it otherwise (Fig. 9). Forestation on ungrazed grassland reduced SOM significantly more than forestation on grazed grassland or native forest. The negative effect of forestation on SOM in páramo grassland was explained by the decrease in soil moisture, which increased SOM losses through mineralization. A negative effect of exotic coniferous species on SOM in mineral soils (standardized mean difference $=-0.7, p=0.08$ ) could partly be explained by the low decomposition rates of the recalcitrant litter of these species (Araujo and Austin, 2015, Farley et al., 2004). The lower SOM in both native and exotic tree plantations and in naturally regenerated forest, compared to native forest, was largely due to the initial conversion of native forest into agricultural land or pastures. Indeed, tree plantations are often established in grazed grassland when the soils are already strongly degraded (Chacón et al., 2009). In cases where forestation had a neutral or positive effect, SOM did not reach the levels of that found in native forest. With respect to organic soils (SOM content $>25 \%$ ), no conclusions could be drawn about the impacts of forestation from the three available studies, in which mineralogy and cold, wet climates were responsible for organic matter accumulation. 


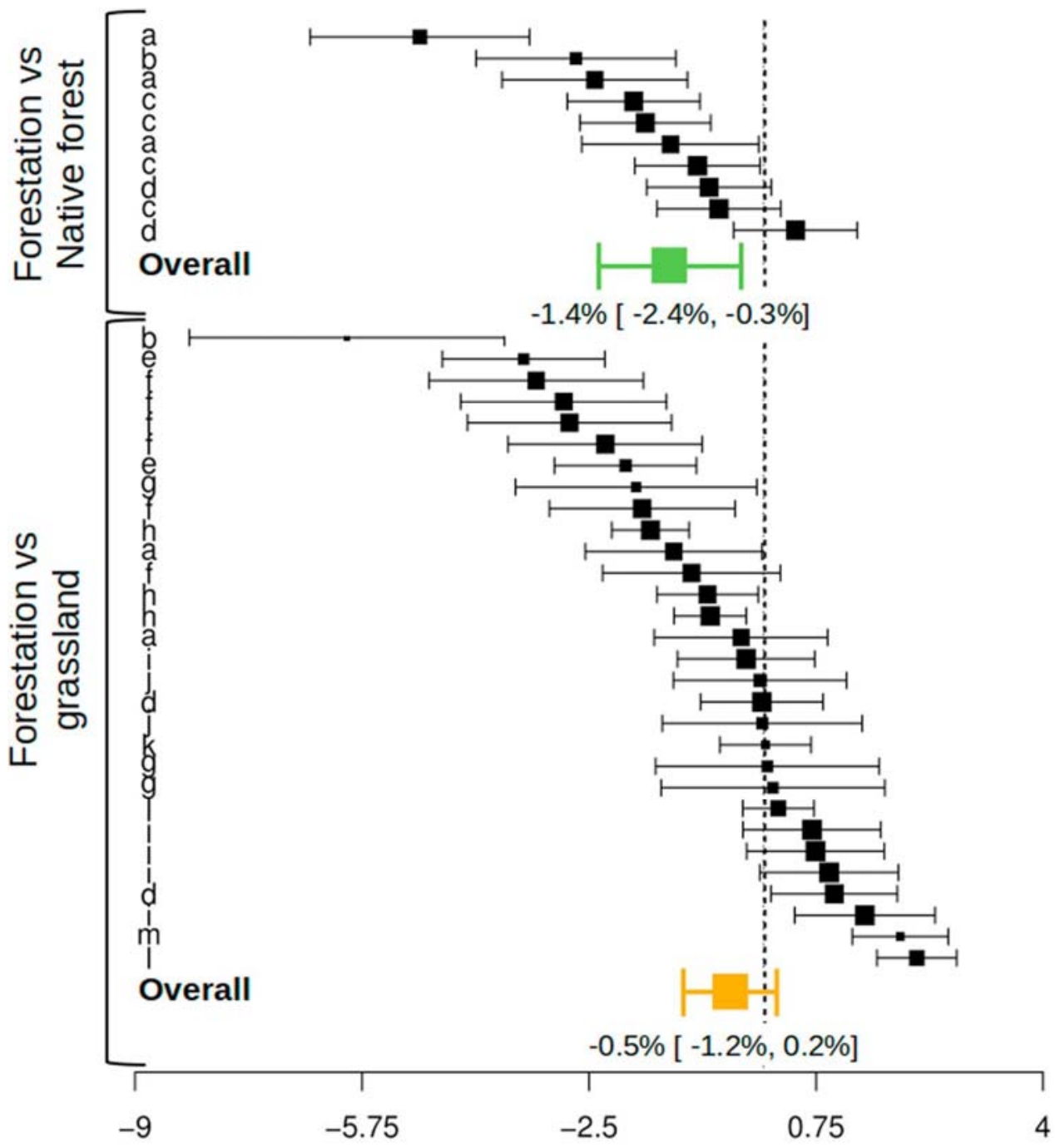

Standardized Mean Difference

Fig. 8. Effect size of soil organic matter content for all studies. The effect size was the standardized mean difference of topsoil organic matter (SOM) between forestation and grassland or native forest divided by the pooled standard deviation. Data with error bars are the effect size estimate at $95 \%$ confidence. The thicker the squares, the higher the study weights. The green error bar is the fixed effect for the comparison between forestation versus native forest estimated on all the studies. The orange error bar is the fixed effect for the comparison between forestation versus grassland estimated on all the studies. The estimated mean in SOM difference (\%) [95\% confidence interval] is shown under the error bars. Letters in the left column refer to studies: $a=$ (Hess et al., 2014), $b=$ (Dube et al., 2009), $c=($ Chacon-Vintimilla, et al., 2003), $d=$ (Rhoades et al., 2000), e = (Molina et al., 2007b), $f=($ Knoke et al., 2014), $g=$ (Henry et al., 2013), $h=$ (Farley et al., 2004), $i=$ (de Koning et al., 2003), $j=$ (Nosetto et al., 2006), $k=$ (Chacón et al., 2009), I = (Bremer et al., 2016), $m=$ (Manna et al., 2016). 


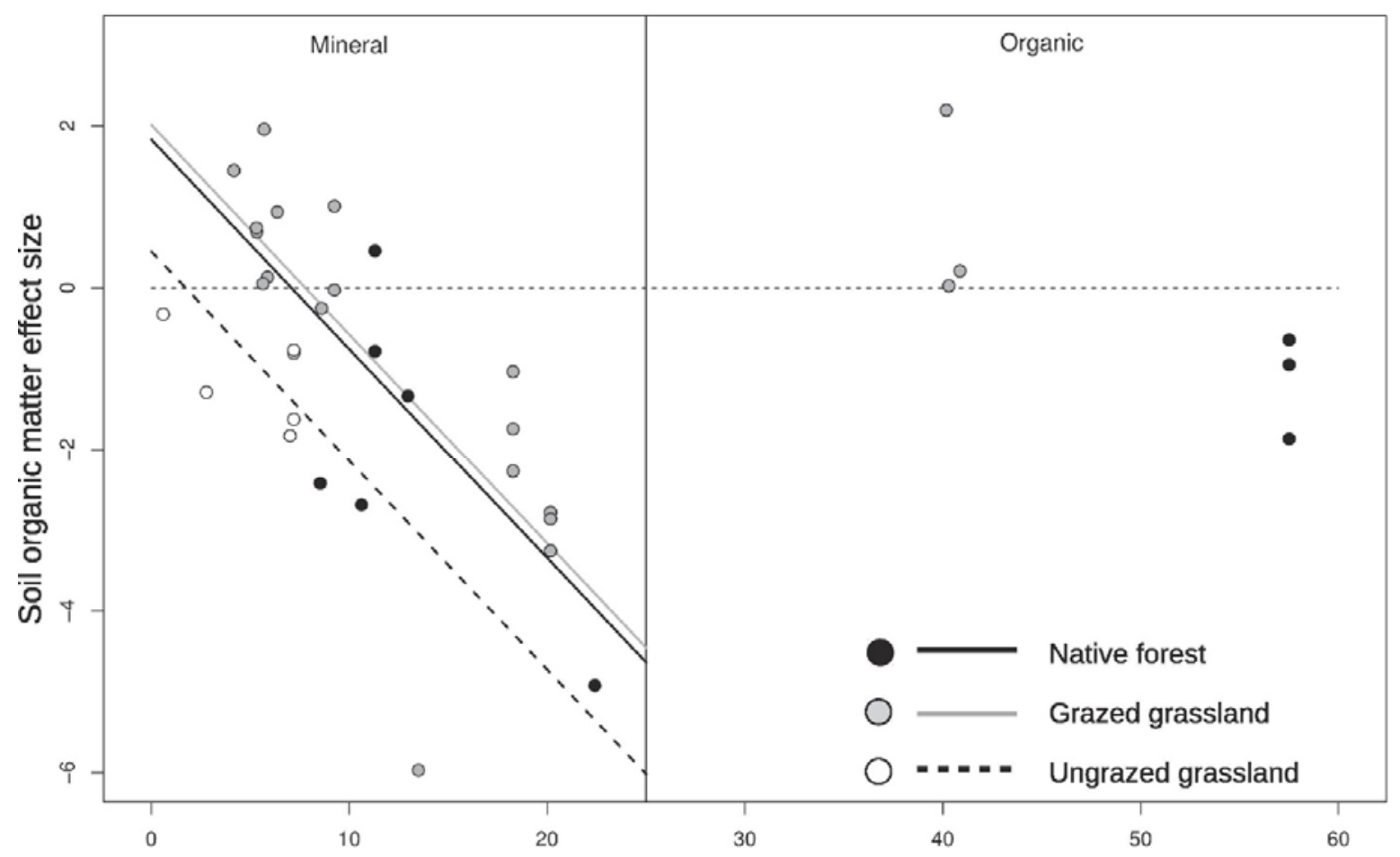

Soil organic matter of the control land use (\%)

Fig. 9. Effect size of soil organic matter (SOM) as a function of the control land use for mineral and organic soils. The effect size is the mean difference of topsoil SOM between forestation and grassland or native forest divided by the pooled standard deviation. Only the most reliable studies are represented. White dots and black dotted line $=$ forestation on undisturbed grassland; gray solid line and dots = forestation on grazed grassland; black solid line and dots $=$ forestation versus native forest.

\section{Discussion}

\subsection{Limitations and strengths of the review}

To our knowledge, this review presents the largest compilation of studies about the impacts of forestation on hydrological services in the Andean region. Although the search and screening protocol aimed at obtaining as many data as possible, it was not always possible to obtain all the information necessary for a comprehensive understanding of the processes occurring. For example, $85 \%$ of the studies examined used a space-for-time substitution, among which $21 \%$ did not report information about land use type before forestation. Such data are desirable because changes in services provision are highly dependent on the initial state of the ecosystem (Balthazar et al., 2015). In this way, the combination of different experimental designs, such as space-for-time substitution (e.g., paired catchments) and time series analysis, gave more strength to conclusions from studies on the impact of exotic tree plantations on water yield, peak flow and low flow. We partially controlled for study quality through sensitivity analyses that showed that conclusions were marginally affected when using only the most reliable studies. 
A strong spatial heterogeneity existed with regard to the distribution of study sites in the Andean cordillera, with an over-representation of regions, e.g., Colombian and Ecuadorian páramo and cloud montane forests which benefit from precipitation rates distributed throughout the year and good soil hydrological properties (high SOM content for andisols in general) (Buytaert et al., 2006). A large variety of soils suitable for forest establishment, e.g., leptosols, cambisols or regosols, with smaller water storage capacity were underrepresented in the review (Gardi et al., 2015). Consequently, there is a need for more research on Andean areas, with the most pressing water challenges (due to e.g., a drier climate and/or smaller soil water storage, mainly in Peruvian and Bolivian Andes), where forestation can play a role in improving water supply and regulation or, on the contrary, worsen existing problems depending on how and where trees are planted.

\subsection{Forestation in the Andes reduces downstream water supply}

Our analysis confirms that exotic tree plantations and to a lesser extent natural forests have a lower water yield compared with non-forested land uses in most Andean regions, as also found at global scale (Farley et al., 2005, Filoso et al., 2017, Zhang et al., 2001). In dry regions of the Andes, rainfall interception by forest canopy is likely to worsen water scarcity. However, native montane cloud forests may be a notable exception, which can have a low tree water use (Bruijnzeel et al., 2010). This phenomenon is especially true when meteorological conditions combine to produce a high amount of air moisture, such as in elfin cloud forest (Bruijnzeel et al., 2011). Although we can expect that forestation results in a lower cloud water interception capacity compared with old native forests, due to less abundant epiphytes and bryophytes capturing air moisture, this difference may not increase throughfall substantially (Köhler et al., 2010). For example, in a lower montane cloud forest in Mexico, cloud water interception was similar in an old-growth forest and a 19-year-old naturally regenerated forest (Holwerda et al., 2010).

Our analysis was limited by the scarcity of information on forestation characteristics (e.g., tree age and density), which restricted our exploration of the factors determining the effects of forestation on hydrological services. Forest managers can use such information to improve soil and water services (Farley et al., 2005, Ilstedt et al., 2016, Jones et al., 2017).

We could not detect any effect of forest characteristics on relative interception: our counter-intuitive finding that stand density did not have much influence on rainfall interception was confirmed by other studies performed at an annual resolution (PonetteGonzález et al., 2015, Soto-Schönherr and Iroumé, 2016). This may have important consequences on forest water-use efficiency since evaporated water by forest canopy is not productive compared with transpired water (Licata et al., 2011). Productive plantations with intensive management may reduce water availability by transpiring large amounts of water but this productive use of water can be more efficient than in other forestation types in terms of the amount of water used per ton of wood produced (Gyenge et al., 2010, Gyenge 
et al., 2011, White et al., 2014). Actually, there is a need for more research on forest wateruse efficiency in tropical Andes to inform decision making on the trade-off between hydrological versus other ecosystem services delivered by forest plantations (Baral et al., 2016).

Our search protocol was not designed to find studies about climate feedback such as atmospheric moisture recycling, i.e. the contribution of land evaporation to local and remote precipitation, typically estimated at the continental scale. With this perspective of atmospheric moisture recycling, evapotranspiration should not be seen as a loss for the society: although water is lost for downstream water users, it may benefit downwind users (Ellison et al., 2017). Climate models highlight the importance of the eastern side of the subtropical Andes for atmospheric moisture transport across the Latin American continent. Remote changes in forest cover (e.g., in the Amazonian forest) can also have major consequences on the hydrologic regime of the Andes (van der Ent et al., 2010).

\subsection{Forestation on degraded soils has positive impacts on hydrological regulation and mitigation of water erosion}

Forestation is often used as a last resort on degraded soils, when croplands or pastures are no longer productive (Chacón et al., 2009). In addition to wood production, exotic tree plantation in the Inter-Andean valley has been extensively used to control soil erosion with overall good results on bare soils. In a systematic quantitative review, the surface vegetation cover was also found to be the driving factor for protecting soils against water erosion in the tropics (Labrière et al., 2015). According to the absence or presence of surface vegetation cover (including litter), tree plantation could either provide poor or excellent protection against soil erosion (Labrière et al., 2015). On steep slopes, management of tree plantation should particularly take care of the surface vegetation cover, avoiding grazing or burning practices. Future research should now focus on the impact of forestation on landslides that have been overlooked although landslides are responsible of important sediment transport (Douglas and Guyot, 2005, Stokes et al., 2008).

Exotic tree plantations on (over)grazed lands clearly improved soil infiltration rates, in agreement with a meta-analysis of tree plantation in the tropics (Ilstedt et al., 2007). Forestation is therefore almost as efficient to reduce Hortonian overland flow as native forests. Forestation on degraded soils also likely decreases total surface runoff. Degraded agricultural lands with low SOM content can also benefit from forestation through increased organic matter content, a pattern also observed in other regions (Minasny et al., 2017). This increase can improve soil water storage although in limited proportion (Minasny and Mcbratney, 2017). Therefore, it is clear that forestation can enhance the infiltration processes on degraded Andean soils. However, higher water use due to forestation has adverse effect on low flow conservation and flood reduction. Substantial rainfall interception by canopy cover further enhances the dampening of strong rainfall and reduces the frequency and 
intensity of moderate rainfall (Iroume and Huber, 2000). However, in case of intense and prolonged rainfall, leading to soil and canopy saturation, forest cover has limited effects on catastrophic flooding (CIFOR and FAO, 2005). Regarding to low flow conservation, there is a well-known trade-off between the forest high water use and its enhanced infiltration (Malmer et al., 2010). In absence of soil degradation, the important water use of exotic tree plantations very often exceeds the increase of soil infiltration leading to strong reduction of low flows, including water shortage during dry seasons (Farley et al., 2005). Exotic tree may increase low flow only when they are planted on degraded soils as in an Ecuadorian catchment (Molina et al., 2012). However, forest management should limit evapotranspiration. For example, the hypothesis of "optimum tree cover" proposes that an intermediate stand density can maximise groundwater recharge (Ilstedt et al., 2016).

Forest restoration initiatives should also take into account the time needed for mitigation of erosion control and hydrological regulation. There is often a fast degradation of ecosystem services and slow recovery, in part because of system hysteresis (i.e. the fact that past system history affects current system state) (Locatelli et al., 2017). Most studies indicating forestation age were concerned with tree plantations $>20$ years old. Results indicated that 20 years was sufficient to reach a significant increase in soil infiltration rate and erosion control similar to that found in native forests. This timespan may even be shorter. For example, "media luna" agroforestry in Bolivia led to improved water infiltration and erosion control in very degraded soils after five years only (Bastian and Gräfe, 1989). In Costa Rica, secondary succession resulted in the restoration of near-surface hydraulic conductivity after pasture abandonment within 12 years (Hassler et al., 2011). In contrast, the recovery of SOM and soil water storage may require much more than 20 years since even when forestation improved SOM content, soils of reforested lands did not reach the levels found in native forests. The lag in recovering ecosystem services enhances the importance of conserving existing native forests (especially montane cloud forests which have a slow growth) for their high capacity of hydrological regulation and control of water erosion through e.g., the payment for environmental services in watershed (Southgate and Wunder, 2009).

\subsection{Restoring hydrological services in Andean forest landscapes}

Forest landscape restoration ( $F L R)$ is an active, long-term process to regain ecological integrity and enhance human well-being in landscapes that have lost forest cover, forest qualities and forest-based contributions to people (Sabogal et al., 2015). Forest landscape restoration is high on the agenda of Andean countries which have committed to restore about 6.2 Mha of degraded lands in the next years (Murcia et al., 2017, World Resources Institute, n.d..). FLR seeks to restore ecosystem functions and services, among which water supply, hydrological regulation and water erosion mitigation are highly desired (IUCN, 2011).

The implications of our results for the sound implementation of forestation activities in the context of broader, forest landscape restoration interventions are many. This review confirms the benefits of restoring forest cover on degraded soils for hydrological services. 
Therefore forest landscape restoration initiatives across the Andes (Murcia et al., 2017) should prioritize degraded soils in order to optimize societal benefits. However, on degraded (overgrazing, burning) páramo and puna grasslands, tree plantation have to be avoided and restoration of native grassland should be preferred given the excellent water supply, hydrological regulation and erosion mitigation of these grassland ecosystems (De Bièvre et al., 2015). Bare soils or soils with a low surface cover are visible features of soil degradation but it is not always as easy to determine the level of soil degradation. For instance, animal treading can create soil compaction, with reduced soil water storage and infiltration capacity (Chandler et al., 2018, Drewry et al., 2008). To inform about the likelihood of soil compaction and degradation, an integrative approach combining remote sensing, cheap in situ assessment and information on past agricultural and pasturing practices should be used (Shoshany et al., 2013).

Our review also suggests that some exotic tree plantations can enhance hydrological regulation and erosion mitigation, in addition to wood provision, avoiding somehow further logging of native forests that provide a high level of these services (Ewel and Putz, 2004). Because we tend to know more about exotic tree species for planting than native ones in Andean ecosystems, the exotic tree plantations should not be discarded from the outset because of their impacts on water yield, provided they are adequately located in the landscape. At the same time, the knowledge gap on the hydrological services provided by forestation with native species (plantation or natural regeneration) should be addressed by future studies to make them more attractive.

Finally, it is important to make people aware that FLR is a long-term process to restore hydrological services. Contrasted perceptions of the impact of forestation on hydrological services exist among Andean stakeholders (Quiroz Dahik et al., 2018) and forests are often perceived by the public as necessarily good for the water environment in all circumstances (Calder, 1998). However, it is clear that in most circumstances, forestation will reduce total water availability for downstream users, especially during the first years of forest growth. To mitigate this reduction of water supply, a system of mosaic management of tree plantation and native forests and grasslands can be adopted across the landscape (Ferraz et al., 2013). At the same time, improvement of hydrological regulation is a slow process that may last more than 20 years. This suggests that forestation outcomes may take some time for society and the environment to show clear benefits. This underscores the well known fact that forest landscape restoration is a long term process during which changes are expected to happen. Therefore, consideration of the different perceptions and a clear adaptive management mindset must accompany any forestation intervention beyond the often used approach of "planting and leaving" without assessing outcomes and impacts. 


\section{Conclusion}

We have reviewed and synthesized a substantial number of studies to inform decision-making about the impacts of forestation on water supply, water erosion and hydrological regulation in the Andean region. Most of the results are in agreement with literature on forest hydrology, such as the detrimental impact of exotic tree plantations on downstream water supply. Many studies have clearly advise against exotic tree plantations on conserved páramo grassland that cause strong loss of hydrological services. Quantitative syntheses emphasized the capacity of forestation to improve the infiltration of degraded Andean soils, which is essential for hydrological regulation. Moreover, forestation have shown good results in mitigating water erosion on degraded soils or soils prone to erosion. Therefore forest landscape restoration initiatives across the Andes should prioritize degraded soils in order to optimize societal benefits. Forest landscape restoration initiatives also seek to conserve the important Andean biodiversity and futures studies should address the knowledge gap on the hydrological services provided by forestation with native species (plantation or natural regeneration) to make them more attractive.

\section{References}

Aide, T.M., Clark, M.L., Grau, H.R., López-Carr, D., Levy, M.A., Redo, D., Bonilla-Moheno, M., Riner, G., Andrade-Núñez, M.J., Muñiz, M., 2013. Deforestation and reforestation of Latin America and the Caribbean (2001-2010). Biotropica 45, 262-271. https://doi.org/10.1111/j.17447429.2012.00908.x.

Araujo, P.I., Austin, A.T., 2015. A shady business: pine afforestation alters the primary controls on litter decomposition along a precipitation gradient in Patagonia, Argentina. J. Ecol. 103, 14081420. https://doi.org/10.1111/1365-2745.12433.

Ataroff, M., Rada, F., 2000. deforestation impact on water dynamics in a venezuelan andean cloud forest. AMBIO: J. Human Environ. 29, 440-444. https://doi.org/10.1579/0044-7447-29.7.440.

Balthazar, V., Vanacker, V., Molina, A., Lambin, E.F., 2015. Impacts of forest cover change on ecosystem services in high Andean mountains. Ecol. Indic. 48, 63-75. https://doi.org/10.1016/j.ecolind.2014.07.043.

Baral, H., Guariguata, M.R., Keenan, R.J., 2016. A proposed framework for assessing ecosystem goods and services from planted forests. Ecosyst. Serv. 22, 260-268. https://doi.org/10.1016/j.ecoser.2016.10.002.

Bastian, E., Gräfe, W., 1989. Afforestation with "multipurpose trees" in "media lunas", a case study from the Tarija basin, Bolivia. Agroforest. Syst. 9, 93-126. https://doi.org/ 10.1007/BF00168257.

Bates, D., Sarkar, D., Bates, M.D., Matrix, L., 2007. The Ime4 Package. R Package Version 2, 74.

Bathurst, J.C., Amezaga, J., Cisneros, F., Novillo, M.G., Iroumé, A., Lenzi, M.A., Aguirre, J.M., Miranda, M., Urciuolo, A., 2010a. Forests and floods in Latin America: science, management, policy and the EPIC FORCE project. Water Int. 35, 114-131. https:// doi.org/10.1080/02508061003660714.

Bathurst, J.C., Birkinshaw, S.J., Cisneros, F., Fallas, J., Iroumé, A., Iturraspe, R., Novillo, M.G., Urciuolo, A., Alvarado, A., Coello, C., Huber, A., Miranda, M., Ramirez, M., Sarandón, R., 2011a. Forest impact on floods due to extreme rainfall and snowmelt in four Latin American environments 2: model analysis. J. Hydrol. 400, 292-304. https://doi.org/10.1016/j.jhydrol.2010.09.001. 
Bathurst, J.C., Bovolo, C.I., Cisneros, F., 2010b. Modelling the effect of forest cover on shallow landslides at the river basin scale. Ecol. Eng. 36, 317-327. https://doi.org/ 10.1016/j.ecoleng.2009.05.001.

Bathurst, J.C., Iroumé, A., Cisneros, F., Fallas, J., Iturraspe, R., Novillo, M.G., Urciuolo, A., de Bièvre, B., Borges, V.G., Coello, C., Cisneros, P., Gayoso, J., Miranda, M., Ramírez, M., 2011b. Forest impact on floods due to extreme rainfall and snowmelt in four Latin American environments 1: field data analysis. J. Hydrol. 400, 281-291. https://doi.org/10.1016/j.jhydrol.2010.11.044.

Brauman, K.A., Daily, G.C., Duarte, T.K., Mooney, H.A., 2007. The nature and value of ecosystem services: an overview highlighting hydrologic services. Annu. Rev. Env. Resour. 32, 67-98. https://doi.org/10.1146/annurev.energy.32.031306.102758.

Bravo Martínez, 2015. Análisis hidrológico y respuesta lluvia-escorrentía de cuatro microcuencas de alta montaña del sur del Ecaudor (MSc Thesis). Universidad de Cuenca, Ecuador.

Bremer, L.L., Farley, K.A., Chadwick, O.A., Harden, C.P., 2016. Changes in carbon storage with land management promoted by payment for ecosystem services. Environ. Conserv. 43, 397-406.

Bruijnzeel, L.A., Calder, I.R., Vertessy, R.A., 2004. Impacts of forest conversion on streamflow. Water Serv. 83, 11-14.

Bruijnzeel, L.A., Kappelle, M., Mulligan, M., Scatena, F.N., 2011. Tropical montane cloud forests: state of knowledge and sustainability perspectives in a changing world. Tropical Montane Cloud Forest. Cambridge University Press, Cambridge, UK.

Bruijnzeel, L.A., Scatena, F.N., Hamilton, L.S., 2010. Tropical Montane Cloud Forests. Cambridge University Press, Cambridge. Bullock, J.M., Aronson, J., Newton, A.C., Pywell, R.F., Rey-Benayas, J.M., 2011. Restoration of ecosystem services and biodiversity: conflicts and opportunities. Trends Ecol. Evol. 26, 541-549. https://doi.org/10.1016/j.tree.2011.06.011.

Buytaert, W., Célleri, R., De Bièvre, B., Cisneros, F., Wyseure, G., Deckers, J., Hofstede, R., 2006. Human impact on the hydrology of the Andean páramos. Earth Sci. Rev. 79, 53-72. https://doi.org/10.1016/j.earscirev.2006.06.002.

Buytaert, W., Iñiguez, V., Bièvre, B.D., 2007. The effects of afforestation and cultivation on water yield in the Andean páramo. For. Ecol. Manage. 251, 22-30. https://doi. org/10.1016/j.foreco.2007.06.035.

Calder, I.R., 1998. Water-Resource and Land-Use Issues. SWIM paper, International Water Management Institute, Colombo.

Calle, Z., Henao-Gallego, N., Giraldo, C., Armbrecht, I., 2013. A comparison of vegetation and grounddwelling ants in abandoned and restored gullies and landslide surfaces in the Western Colombian Andes. Restor. Ecol. 21, 729-735. https://doi.org/10.1111/ rec.12001.

Catchpole, D.J., 2012. Orographic Gradients in Climate and Forest Cover at the Cordillera Yanachaga, Peru (PhD Thesis). University of Tasmania.

Célleri, R., Feyen, J., 2009. The hydrology of tropical andean ecosystems: importance, knowledge status, and perspectives. Mt. Res. Dev. 29, 350-355. https://doi.org/10. 1659/mrd.00007.

Cerdà, A., 2000. Aggregate stability against water forces under different climates on agriculture land and scrubland in southern Bolivia. Soil Till. Res. 57, 159-166. https://doi.org/10.1016/S01671987(00)00155-0.

Chacón, G., Gagnon, D., Paré, D., 2009. Comparison of soil properties of native forests, Pinus patula plantations and adjacent pastures in the Andean highlands of southern Ecuador: land use history or recent vegetation effects? Soil Use Manage. 25, 427-433. https://doi.org/10.1111/j.1475-2743.2009.00233.x.

Chacon-Vintimilla, G., Gagnon, D., Paré, D., Proulx, D., 2003. Impacto de la deforestación, pastizales, plantaciones de eucalipto y pino en suelos de bosque montano alto, en la sierra sur del ecuador. Rev. Invest. Uni, Azuay. 
Chandler, K.R., Stevens, C.J., Binley, A., Keith, A.M., 2018. Influence of tree species and forest land use on soil hydraulic conductivity and implications for surface runoff generation. Geoderma 310, 120-127. https://doi.org/10.1016/j.geoderma.2017.08. 011.

Chepstow-Lusty, A., Winfield, M., 2000. Inca agroforestry: lessons from the past. Ambio 29, 322-328. CIFOR, FAO (Eds.), 2005. Forests and floods: drowning in fiction or thriving on facts? RAP publication/Food and Agriculture Organization of the United Nations, Regional Office for Asia and the Pacific. Center for International Forestry Research, Bogor Barat, Indonesia.

Cincotta, R.P., Wisnewski, J., Engelman, R., 2000. Human population in the biodiversity hotspots. Nature 404, 990. Collaboration for Environmental Evidence, 2013. Guidelines for Systematic Reviews in Environmental Management (no. Version 4.2). Environmental Evidence.

Cooper, H.M., Hedges, L.V. (Eds.), 1994. Handbook of Research Synthesis. Cooper \& Hedges.

Crockford, R.H., Richardson, D.P., 2000. Partitioning of rainfall into throughfall, stemflow and interception: effect of forest type, ground cover and climate. Hydrol. Process. 14, 2903-2920. https://doi.org/10.1002/1099-1085(200011/12)14:16/ 17<2903::AID-HYP126>3.0.CO;2-6.

De Bièvre, B., Calle, T., Borja, P., Nuñez, J., 2015. Restoration of Overgrazed Páramo Grasslands for Hydrological Benefits. FAO. de Koning, G.H.J., Veldkamp, E., López-Ulloa, M., 2003. Quantification of carbon sequestration in soils following pasture to forest conversion in northwestern Ecuador. Global Biogeochem. Cy. 17. https://doi.org/10.1029/2003GB002099.

Díaz Betancourt, E.B., 2008. Distribución del contenido de carbono orgánico en agregados de diferentes tamaños, procedentes de varios sistemas de uso y altitudes en suelos de la Cuenca del rió Cauca, Colombia (MSc Thesis). Universidad Nacional de Colombia Sede Palmira.

Doornbos, B., 2015. El valor de los bosques andinos en asegurar agua y suelo en un contexto de creciente riesgo climático: ¿(re)conocemos lo imperdible?

Douglas, I., Guyot, J.L., 2005. Erosion and sediment yield in the humid tropics. In: Bonell, M., Bruijnzeel, L.A. (Eds.), Forests, Water and People in the Humid Tropics: Past, Present and Future Hydrological Research for Integrated Land and Water Management, pp. 407-422.

Drewry, J.J., Cameron, K.C., Buchan, G.D., 2008. Pasture yield and soil physical property responses to soil compaction from treading and grazing - a review. Soil Res. 46, 237-256. https://doi.org/10.1071/SR07125.

Dube, F., Zagal, E., Stolpe, N., Espinosa, M., 2009. The influence of land-use change on the organic carbon distribution and microbial respiration in a volcanic soil of the Chilean Patagonia. For. Ecol. Manage. 257.

Duque Zapata, J.R., Arbelaez Mesa, S.P., Jaramillo Jaramillo, D.F., Leon Pelaez, J.D., 2004. Hydrophobicity of Andisols of oak groves (Quercus humboldtii) and tree plantations (Pinus patula and Cupressus lusitanica) in the Piedras Blancas watershed (Medellín, Colombia). Rev. Fac. Nac. Agron. Medellin 57, 2423-2434.

Ellison, D., Morris, C.E., Locatelli, B., Sheil, D., Cohen, J., Murdiyarso, D., Gutierrez, V., van Noordwijk, M., Creed, I.F., Pokorny, J., Gaveau, D., Spracklen, D.V., Tobella, A.B., Ilstedt, U., Teuling, A.J., Gebrehiwot, S.G., Sands, D.C., Muys, B., Verbist, B., Springgay, E., Sugandi, Y., Sullivan, C.A., 2017. Trees, forests and water: cool insights for a hot world. Global Environ. Chang. 43, 51-61. https://doi.org/10.1016/j. gloenvcha.2017.01.002.

Ewel, J.J., Putz, F.E., 2004. A place for alien species in ecosystem restoration. Front. Ecol. Environ. 2, 354-360. https://doi.org/10.1890/1540-9295(2004) 002[0354:APFASI] 2.0.CO;2. Farley, K.A., 2007. Grasslands to tree plantations: forest transition in the Andes of Ecuador. Ann. Assoc. Am. Geogr. 97, 755-771. https://doi.org/10.1111/j.1467- 8306.2007.00581.x.

Farley, K.A., Jobbágy, E.G., Jackson, R.B., 2005. Effects of afforestation on water yield: a global synthesis with implications for policy. Glob. Change Biol. 11, 1565-1576.

https://doi.org/10.1111/j.1365-2486.2005.01011.x. 
Farley, K.A., Kelly, E.F., Hofstede, R.G.M., 2004. Soil organic carbon and water retention after conversion of grasslands to pine plantations in the Ecuadorian Andes. Ecosystems 7, 729-739. https://doi.org/10.1007/s10021-004-0047-5.

Ferraz, S.F.B., Lima, W.deP., Rodrigues, C.B., 2013. Managing forest plantation landscapes for water conservation. For. Ecol. Manage. 301, 58-66. https://doi.org/10. 1016/j.foreco.2012.10.015.

Filoso, S., Bezerra, M.O., Weiss, K.C., Palmer, M.A., 2017. Impacts of forest restoration on water yield: a systematic review. PLoS ONE 12, e0183210.

Fleischbein, K., Wilcke, W., Goller, R., Valarezo, C., Zech, W., Knoblich, K., 2011. Measured and modeled rainfall interception in a lower montane forest, Ecuador. In: Bruijnzeel, L.A., Scatena, F.N., Hamilton, L.S. (Eds.), Tropical Montane Cloud Forests. Cambridge University Press.

Fleischbein, K., Wilcke, W., Valarezo, C., Zech, W., Knoblich, K., 2006. Water budgets of three small catchments under montane forest in Ecuador: experimental and modelling approach. Hydrol. Process. 20, 2491-2507. https://doi.org/10.1002/hyp.6212.

Gaitán, L.C., Armbrecht, I., Graefe, S., 2016. Throughfall and soil properties in shaded and unshaded coffee plantations and a secondary forest: a case study from Southern Colombia. J. Agric. Rural Dev. Trop. Subtrop. 117, 309-321.

García Olmos, C.F., 2007. Regulación hídrica bajo tres coberturas vegetales en la cuenca del Rio San Cristóbal, Bogotá D.C. Colomb. For. 10, 127-147.

Gardi, C., Angelini, M., Barceló, S., Comerma, J., Cruz Gaistardo, C., Encina Rojas, A., Jones, A., Krasilnikov, P., Mendonça Santos Brefin, M.L., MuñizUgarte, O., Schad, P., Vara Rodríguez, M.I., Vargas, R., 2015. Soil atlas of Latin America and the Caribbean. European Comission, Publications Office of the European Union, L-2995 Luxembourg.

Gomez-Peralta, D., Oberbauer, S.F., McClain, M.E., Philippi, T.E., 2008. Rainfall and cloud-water interception in tropical montane forests in the eastern Andes of Central Peru. For. Ecol. Manage. 255, 1315-1325. https://doi.org/10.1016/j.foreco.2007.10. 058.

Gonzalez Alfaro, G., 2015. Caracterización de la infiltración en bosques plantados con Polylepis spp., de 11 y 29 años, parque nacional Huascarán, quebrada Quilcayhuanca, Huaraz, Ancash (MSc Thesis). Universidad Nacional Agraria La Molina.

Gonzalez, J., 2011. Measuring cloud water interception in the Tambito forests of southern Colombia. In: Bruijnzeel, L.A., Scatena, F.N., Hamilton, L.S. (Eds.), Tropical Montane Cloud Forests. Cambridge University Press.

Guns, M., Vanacker, V., 2013. Forest cover change trajectories and their impact on landslide occurrence in the tropical Andes. Environ. Earth Sci. 70, 2941-2952. https://doi.org/10.1007/s12665-013-2352-9.

Gyenge, J., Fernandez, M.E., Rusch, V., Sarasola, M., Schlichter, T.M., 2010. Towards sustainable forestry development in Patagonia: truths and myths of environmental impacts of plantations with fast-growing conifers. Am. J. Plant Sci. Biotechnol. 3.

Gyenge, J., Fernández, M.E., Schlichter, T., 2009. Effects on site water balance of conversion from native mixed forest to Douglas-fir plantation in N.W. Patagonia. New Forest. 38, 67-80. https://doi.org/10.1007/s11056-009-9132-0.

Gyenge, J.E., Elena Fernández, M., Licata, J., Weigandt, M., Bond, B.J., Schlichter, T.M., 2011. Uso del agua y productividad de los bosques nativos e implantados en el NO de la patagonia: aproximaciones desde la ecohidrología y la ecofisiología. Ecol. Austral 21, 271-284.

Harden, C., 1992. A new look at soil erosion processes on hillslopes in highland Ecuador. Proceedings of the IAH/IAHS Guilin Symposium. Presented at the Erosion, Debris Flows and Environment in Mountain Regions, Chengdu.

Harden, C.P., 2006. Human impacts on headwater fluvial systems in the northern and central Andes. Geomorphology 79, 249-263. https://doi.org/10.1016/j.geomorph. 2006.06.021. 
Harden, C.P., 1996. Interrelationships between land abandonment and land degradation: a case from the Ecuadorian Andes. Mt. Res. Dev. 16, 274-280.

Harden, C.P., Hartsig, J., Farley, K.A., Lee, J.H., Bremer, L.L., 2013. Effects of land-use change on water in Andean paramo grassland soils. Ann. Assoc. Am. Geogr. 103, 375-384.

Harden, J.W., Hugelius, G., Ahlström, A., Blankinship, J.C., Bond-Lamberty, B., Lawrence, C.R., Loisel, J., Malhotra, A., Jackson, R.B., Ogle, S., Phillips, C., Ryals, R., Todd- Brown, K., Vargas, R., Vergara, S.E., Cotrufo, M.F., Keiluweit, M., Heckman, K.A., Crow, S.E., Silver, W.L., DeLonge, M., Nave, L.E., 2018. Networking our science to characterize the state, vulnerabilities, and management opportunities of soil organic matter. Glob. Change Biol. 24, e705-e718. https://doi.org/10.1111/gcb.13896.

Hassler, S.K., Zimmermann, B., van Breugel, M., Hall, J.S., Elsenbeer, H., 2011. Recovery of saturated hydraulic conductivity under secondary succession on former pasture in the humid tropics. For. Ecol. Manage. 261, 1634-1642. https://doi.org/10.1016/j. foreco.2010.06.031.

Henry, A., Mabit, L., Jaramillo, R.E., Cartagena, Y., Lynch, J.P., 2013. Land use effects on erosion and carbon storage of the Río Chimbo watershed, Ecuador. Plant Soil 367, 477-491. https://doi.org/10.1007/s11104-012-1478-y.

Hess, L.J.T., Austin, A.T., Vries, F., 2014. Pinus ponderosa alters nitrogen dynamics and diminishes the climate footprint in natural ecosystems of Patagonia. J. Ecol. 102.

Higgins, J., Green, S., 2011. Cochrane Handbook for Systematic Reviews of Interventions. The Cochrane Collaboration.

Hofstede, R.G.M., Groenendijk, J.P., Coppus, R., Fehse, J.C., Sevink, J., 2002. Impact of pine plantations on soils and vegetation in the Ecuadorian high Andes. Mt. Res. Dev. 22, 159-167. https://doi.org/10.1659/0276-4741(2002) 022[0159:IOPPOS]2.0. CO;2.

Holwerda, F., Bruijnzeel, L.A., Muñoz-Villers, L.E., Equihua, M., Asbjornsen, H., 2010. Rainfall and cloud water interception in mature and secondary lower montane cloud forests of central Veracruz, Mexico. J. Hydrol. 384, 84-96. https://doi.org/10.1016/ j.jhydrol.2010.01.012.

Hoyos, N., 2005. Spatial modeling of soil erosion potential in a tropical watershed of the Colombian Andes. Catena 63, 85-108. https://doi.org/10.1016/j.catena.2005.05. 012.

Huber, A., Trecaman, R., 2002. The effect of the inter-annual variability of rainfall on the development of Pinus radiata (D. Don) plantations in the sandy soil zones of VIII region of Chile. Bosque 23, 43-49.

Ilstedt, U., Bargués Tobella, A., Bazié, H.R., Bayala, J., Verbeeten, E., Nyberg, G., Sanou, J., Benegas, L., Murdiyarso, D., Laudon, H., Sheil, D., Malmer, A., 2016. Intermediate tree cover can maximize groundwater recharge in the seasonally dry tropics. Sci. Rep.-UK 6. https://doi.org/10.1038/srep21930.

Ilstedt, U., Malmer, A., Verbeeten, E., Murdiyarso, D., 2007. The effect of afforestation on water infiltration in the tropics: a systematic review and meta-analysis. For. Ecol. Manage. 251, 4551. https://doi.org/10.1016/j.foreco.2007.06.014.

Inbar, M., Llerena, C.A., 2000. Erosion processes in high mountain agricultural terraces in Peru. Mt. Res. Dev. 20, 72-79. https://doi.org/10.1659/0276-4741(2000) 020[0072:EPIHMA]2.0.CO;2.

Iroume, A., Huber, A., 2000. Forest canopy interception and effects on peak flows in an experimental catchment at Malalcahuello, IX Region, Chile. Bosque 21, 45-56.

Iroumé, A., Palacios, H., 2013. Afforestation and changes in forest composition affect runoff in large river basins with pluvial regime and Mediterranean climate, Chile. J. Hydrol. 505, 113-125. https://doi.org/10.1016/j.jhydrol.2013.09.031. IUCN, 2011. Bonn Challenge [WWW Document]. URL<http://www.bonnchallenge. org > (accessed 4.6.18). 
Jackson, R.B., Jobbagy, E.G., Avissar, R., Roy, S.B., Barrett, D.J., Cook, C.W., Farley, K.A., le Maitre, D.C., McCarl, B.A., Murray, B.C., 2005. Trading water for carbon with biological carbon sequestration. Science 310.

Jaramillo Jaramillo, D.F., Vanegas Villa, H.A., 2007. Drying temperature, persistence and spatial variability of water repellency in andisols of Antioquia, Colombia. Rev. Fac. Nac. Agron. Medellin 60, 4025-4035.

Jarvis, A., Reuter, H.I., Nelson, A., Guevara, E., 2008. Hole-filled SRTM for the globe Version 4. Jones, J., Almeida, A., Cisneros, F., Iroumé, A., Jobbágy, E., Lara, A., Lima, W.deP., Little, C., Llerena, C., Silveira, L., Villegas, J.C., 2017. Forests and water in South America. Hydrol. Process. 31, 972980. https://doi.org/10.1002/hyp.11035.

Josse, C., Cuesta, F., Navarro, G., Barrena, V., Becerra, M.T., Cabrera, E., Chacón-Moreno, E., Ferreira, W., Peralvo, M., Saito, J., et al., 2011. Physical geography and ecosystems in the tropical Andes. In: Herzog, S.K., Martínez, R., Jørgensen, P.M., Tiessen, H. (comps.), Climate Change and Biodiversity in the Tropical Andes, pp. 152-169.

Kessler, M., 2002. The "Polylepis problem": where do we stand? Ecotropica 8, 97-110. Knoke, T., Bendix, J., Pohle, P., Hamer, U.K., Hildebrandt, P., Roos, K., Gerique, A., Sandoval, M.L., Breuer, L., Tischer, A., Silva, B., Calvas, B., Aguirre, N., Castro, L.M., Windhorst, D., Weber, M., Stimm, B., Günter, S.L., Palomeque, X., Mora, J., Mosandl, R., Beck, E., 2014. Afforestation or intense pasturing improve the ecological and economic value of abandoned tropical farmlands. Nat. Commun. 5. https://doi.org/ 10.1038/ncomms6612.

Köhler, L., Hölscher, D., Bruijnzeel, L.A., Leuschner, C., Hamilton, L.S.B., 2010. Epiphyte biomass in Costa Rican old-growth and secondary montane rain forests and its hydrological significance. In: Tropical Montane Cloud Forests. Science for Conservation and Management. Cambridge University Press, pp. 268-274.

Körner, C., Paulsen, J., 2004. A world-wide study of high altitude treeline temperatures. J. Biogeogr. 31, 713-732.

Labrière, N., Locatelli, B., Laumonier, Y., Freycon, V., Bernoux, M., 2015. Soil erosion in the humid tropics: a systematic quantitative review. Agr. Ecosyst. Environ. 203, 127-139. https://doi.org/10.1016/j.agee.2015.01.027.

León Peláez, J.D., González Hernández, M.I., Gallardo Lancho, J.F., 2010. Distribución del agua lluvia en tres bosques altoandinos de la cordillera Central de Antioquia, Colombia. Rev. Fac. Nac. Agron. Medellin, pp. 63.

Licata, J.A., Pypker, T.G., Weigandt, M., Unsworth, M.H., Gyenge, J.E.E., Fernández, M.E.E., Schlichter, T.M., Bond, B.J., 2011. Decreased rainfall interception balances increased transpiration in exotic ponderosa pine plantations compared with native cypress stands in Patagonia, Argentina. Ecohydrology 4, 83-93. https://doi.org/10. 1002/eco.125.

Locatelli, B., Lavorel, S., Sloan, S., Tappeiner, U., Geneletti, D., 2017. Characteristic trajectories of ecosystem services in mountains. Front. Ecol. Environ. 15, 150-159. https://doi.org/10.1002/fee.1470.

Locatelli, B., Vignola, R., 2009. Managing watershed services of tropical forests and plantations: can meta-analyses help? For. Ecol. Manage. 258, 1864-1870. https:// doi.org/10.1016/j.foreco.2009.01.015.

Malmer, A., Murdiyarso, D., (Sampurno) Bruijnzeel, L.A., Ilstedt, U., 2010. Carbon sequestration in tropical forests and water: a critical look at the basis for commonly used generalizations. Global Change Biol. 16, 599-604. https://doi.org/10.1111/j. 1365-2486.2009.01984.x.

Manna, L.la., Guillermo Buduba, C., Rostagno, C.M., 2016. Soil erodibility and quality of volcanic soils as affected by pine plantations in degraded rangelands of NW Patagonia. Eur. J. For. Res. 135, 643-655. 
Minasny, B., Malone, B.P., McBratney, A.B., Angers, D.A., Arrouays, D., Chambers, A., Chaplot, V., Chen, Z.-S., Cheng, K., Das, B.S., Field, D.J., Gimona, A., Hedley, C.B., Hong, S.Y., Mandal, B., Marchant, B.P., Martin, M., McConkey, B.G., Mulder, V.L., O'Rourke, S., Richer-de-Forges, A.C., Odeh, I., Padarian, J., Paustian, K., Pan, G., Poggio, L., Savin, I., Stolbovoy, V., Stockmann, U., Sulaeman, Y., Tsui, C.-C., Vågen, T.-G., van Wesemael, B., Winowiecki, L., 2017. Soil carbon 4 per mille. Geoderma 292, 59-86. https://doi.org/10.1016/j.geoderma.2017.01.002.

Minasny, B., Mcbratney, A.B., 2017. Limited effect of organic matter on soil available water capacity: limited effect of organic matter on soil water retention. Eur. J. Soil Sci. https://doi.org/10.1111/ejss.12475.

Molina, A., Govers, G., Cisneros, F., Vanacker, V., 2009. Vegetation and topographic controls on sediment deposition and storage on gully beds in a degraded mountain area. Earth Surf. Process. Landf. 34, 755-767. https://doi.org/10.1002/esp.1747.

Molina, A., Govers, G., Poesen, J., Van Hemelryck, H., De Bièvre, B., Vanacker, V., 2007a. Environmental factors controlling spatial variation in sediment yield in a central Andean mountain area. Geomorphology 98, 176-186. https://doi.org/10.1016/j. geomorph.2006.12.025.

Molina, A., Govers, G., Vanacker, V., Poesen, J., Zeelmaekers, E., Cisneros, F., 2007b. Runoff generation in a degraded Andean ecosystem: interaction of vegetation cover and land use. Catena 71, 357-370.

Molina, A., Vanacker, V., Balthazar, V., Mora, D., Govers, G., 2012. Complex land cover change, water and sediment yield in a degraded Andean environment. J. Hydrol. 472-473, 25-35. https://doi.org/10.1016/j.jhydrol.2012.09.012.

Molina, A., Vanacker, V., Brisson, E., Mora, D., Balthazar, V., 2015. Multidecadal change in streamflow associated with anthropogenic disturbances in the tropical Andes. Hydrol. Earth Syst. Sci. 19, 4201-4213.

Molina Verdugo, A., Govers, G., Van den Putte, A., Poesen, J., Vanacker, V., 2009. Assessing the reduction of the hydrological connectivity of gully systems through vegetation restoration: field experiments and numerical modelling. Hydrol. Earth Syst. Sci. 13, 1823-1836.

Moreno Vallejo, E., 2012. Efectos de diferentes tipos de vegetación sobre la capacidad de infiltración de agua en suelos de páramos en la Reserva Privada Paluguillo (Ecuador) (BSc Thesis).

Morris, A., 1997. Afforestation projects in highland Ecuador: patterns of success and failure. Mt. Res. Dev. 17, 31-42. https://doi.org/10.2307/3673911.

Motzer, T., Munz, N., Anhuf, D., Küppers, M., 2011. Transpiration and microclimate of a tropical montane rain forest, southern Ecuador. In: Bruijnzeel, L.A., Scatena, F.N., Hamilton, L.S. (Eds.), Tropical Montane Cloud Forests. Cambridge University Press.

Muenchow, J., Brenning, A., Richter, M., 2012. Geomorphic process rates of landslides along a humidity gradient in the tropical Andes. Geomorphology 139-140, 271-284. https://doi.org/10.1016/j.geomorph.2011.10.029.

Mulligan, M., Jarvis, A., González, J., Bruijnzeel, L.A., 2011. Using "biosensors" to elucidate rates and mechanisms of cloud water interception by epiphytes, leaves, and branches in a sheltered Colombian cloud forest. In: Bruijnzeel, L.A., Scatena, F.N., Hamilton, L.S. (Eds.), Tropical Montane Cloud Forests. Cambridge University Press.

Murcia, C., Guariguata, M.R., Peralvo, M., Gálmez, V., 2017. La restauración de bosques andinos tropicales: Avances, desafíos y perspectivas del futuro. Center for International Forestry Research (CIFOR).

Nosetto, M.D., Jobbágy, E.G., Paruelo, J.M., 2006. Carbon sequestration in semi-arid rangelands: comparison of Pinus ponderosa plantations and grazing exclusion in NW Patagonia. J. Arid Environ. 67, 142-156. https://doi.org/10.1016/j.jaridenv.2005. 12.008.

Ochoa-Sánchez, A., Crespo, P., Célleri, R., 2018. Quantification of rainfall interception in the high Andean tussock grasslands. Ecohydrology e1946. https://doi.org/10.1002/ eco.1946. 
Ochoa-Tocachi, B.F., Buytaert, W., Antiporta, J., Acosta, L., Bardales, J.D., Célleri, R., Crespo, P., Fuentes, P., Gil-Ríos, J., Guallpa, M., Llerena, C., Olaya, D., Pardo, P., Rojas, G., Villacís, M., Villazón, M., Viñas, P., De Bièvre, B., 2018. High-resolution hydrometeorological data from a network of headwater catchments in the tropical Andes. Sci. Data 5, 180080. https://doi.org/10.1038/sdata.2018.80.

Ochoa-Tocachi, B.F., Buytaert, W., De Bièvre, B., 2016a. Regionalization of land-use impacts on streamflow using a network of paired catchments. Water Resour. Res. 52, 6710-6729. https://doi.org/10.1002/2016WR018596.

Ochoa-Tocachi, B.F., Buytaert, W., De Bièvre, B., Célleri, R., Crespo, P., Villacís, M., Llerena, C.A., Acosta, L., Villazón, M., Guallpa, M., Gil-Ríos, J., Fuentes, P., Olaya, D., Viñas, P., Rojas, G., Arias, S., 2016b. Impacts of land use on the hydrological response of tropical Andean catchments. Hydrol. Process. 30, 4074-4089. https://doi.org/10. 1002/hyp.10980.

Panagos, P., Ballabio, C., Borrelli, P., Meusburger, K., Klik, A., Rousseva, S., Tadic, M.P., Michaelides, S., Hrabalíková, M., Olsen, P., Aalto, J., Lakatos, M., Rymszewicz, A., Dumitrescu, A., Beguería, S., Alewell, C., 2015. Rainfall erosivity in Europe. Sci. Total Environ. 511, 801-814. https://doi.org/10.1016/j.scitotenv.2015.01.008.

Payeur-Poirier, J.-L., Nguyen, T.T., 2017. The inclusion of forest hydrological services in the sustainable development strategy of South Korea. Sustainability 9, 1470. https:// doi.org/10.3390/su9081470.

Peralta, H.F., Ataroff, M., 2005. Dinamica hídrica en la selva nublada de la cuenca alta del rio cusiana y un pastizal de reemplazo, cordillera oriental, Colombia. In: Ataroff, M., Silva, J.F. (Eds.), Dinámica Hídrica En Sistemas Neotropicales. ICAE,Univ. Los Fonseca, Andes, Mérida, H. y Ataroff, Venezuela M.

Ponette-González, A.G., Brauman, K.A., Marín-Spiotta, E., Farley, K.A., Weathers, K.C., Young, K.R., Curran, L.M., 2015. Managing water services in tropical regions: from land cover proxies to hydrologic fluxes. Ambio 44, 367-375. https://doi.org/10. 1007/s13280-014-0578-8.

Ponette-González, A.G., Marín-Spiotta, E., Brauman, K.A., Farley, K.A., Weathers, K.C., Young, K.R., 2014. Hydrologic connectivity in the high-elevation tropics: heterogeneous responses to land change. BioScience 64, 92-104. https://doi.org/10.1093/ biosci/bit013.

Quichimbo, P., Tenorio, G., Borja, P., Cárdenas, I., Crespo, P., Célleri, R., 2012. Efectos sobre las propiedades físicas y químicas de los suelos por el cambio de la cobertura vegetal y uso del suelo: páramo de Quimsacocha al sur del Ecuador. Suelos Ecuatoriales 42, 138-153.

Quiroz Dahik, C., Crespo, P., Stimm, B., Murtinho, F., Weber, M., Hildebrandt, P., 2018. Contrasting stakeholders' perceptions of pine plantations in the páramo ecosystem of Ecuador. Sustainability 10, 1707. https://doi.org/10.3390/su10061707.

Rhoades, C.C., Eckert, G.E., Coleman, D.C., 2000. Soil carbon differences among forest, agriculture, and secondary vegetation in lower montane ecuador. Ecol. Appl. 10, 497-505.

Roa-García, M.C., Brown, S., Schreier, H., Lavkulich, L.M., 2011. The role of land use and soils in regulating water flow in small headwater catchments of the Andes. Water Resour. Res. 47. https://doi.org/10.1029/2010WR009582.

Roa-García, M.C., Weiler, M., 2010. Integrated response and transit time distributions of watersheds by combining hydrograph separation and long-term transit time modeling. Hydrol. Earth Syst. Sc. 14, 1537-1549. https://doi.org/10.5194/hess-14-1537- 2010.

Sabogal, C., Besacier, C., McGuire, D., 2015. Forest and landscape restoration: concepts, approaches and challenges for implementation. Unasylva 66.

Sadeghian, S., Orozco, L.O., Murgueitio, E., 2001. Soil monitoring in agroecosystems of high montain zone in Quindio. Suelos Ecuatoriales 31, 197-201.

Sáenz, L., Mulligan, M., Arjona, F., Gutierrez, T., 2014. The role of cloud forest restoration on energy security. Ecosyst. Serv. 9, 180-190. https://doi.org/10.1016/j.ecoser. 2014.06.012. 
Sarmiento, F.O., Frolich, L.M., 2002. Andean cloud forest tree lines: naturalness, agriculture and the human dimension. Mount. Res. Dev. 22, 278-287. https://doi.org/ 10.1659/02764741(2002)022[0278:ACFTL]2.0.CO;2.

Shoshany, M., Goldshleger, N., Chudnovsky, A., 2013. Monitoring of agricultural soil degradation by remote-sensing methods: a review. Int. J. Remote Sens. 34, 6152-6181. https://doi.org/10.1080/01431161.2013.793872.

Soto-Schönherr, S., Iroumé, A., 2016. How much water do Chilean forests use? A review of interception losses in forest plot studies. Hydrol. Process. 30, 4674-4686. https:// doi.org/10.1002/hyp.10946.

Southgate, D., Wunder, S., 2009. Paying for watershed services in Latin America: a review of current initiatives. J. Sustain. For. 28, 497-524. https://doi.org/10.1080/ 10549810902794493.

Stehr, A., Aguayo, M., Link, O., Parra, O., Romero, F., Alcayaga, H., 2010. Modelling the hydrologic response of a mesoscale Andean watershed to changes in land use patterns for environmental planning. Hydrol. Earth Syst. Sc. 14, 1963-1977. https://doi.org/ 10.5194/hess14-1963-2010.

Stehr, A., Debels, P., Romero, F., Alcayaga, H., 2008. Hydrological modelling with SWAT under conditions of limited data availability: evaluation of results from a Chilean case study. Hydrolog. Sci. J. 53, 588-601.

Stokes, A., Douglas, G.B., Fourcaud, T., Giadrossich, F., Gillies, C., Hubble, T., Kim, J.H., Loades, K.W., Mao, Z., McIvor, I.R., Mickovski, S.B., Mitchell, S., Osman, N., Phillips, C., Poesen, J., Polster, D., Preti, F., Raymond, P., Rey, F., Schwarz, M., Walker, L.R., 2014. Ecological mitigation of hillslope instability: ten key issues facing researchers and practitioners. Plant Soil 377, 1-23. https://doi.org/10.1007/s11104-014- 2044-6.

Stokes, A., Norris, J.E., Beek, L.P.H.van, Bogaard, T., Cammeraat, E., Mickovski, S.B., Jenner, A., Iorio, A.D., Fourcaud, T., 2008. How vegetation reinforces soil on slopes. In: Norris, J.E., Stokes, A., Mickovski, S.B., Cammeraat, E., Beek, R.van, Nicoll, B.C., Achim, A. (Eds.), Slope Stability and Erosion Control: Ecotechnological Solutions. Springer, Netherlands, pp. 65-118. https://doi.org/10.1007/978-1-4020-6676-4_4.

Tobón, C., 2009. Los bosques andinos y el agua (No. Serie investigación y sistematización \#4). Programa Regional ECOBONA - INTERCOOPERATION, CONDESAN, Quito.

Torres-Salinas, R., Azocar Garcia, G., Carrasco Henriquez, N., Zambrano-Bigiarini, M., Costa, T., Bolin, B., 2016. Forestry development, water scarcity, and the Mapuche protest for environmental justice in Chile. (Special Issue: Water scarcity and human rights.). Amb. Soc. 19, 121-144.

Trabucco, A., Zomer, R.J., 2009. Global Potential Evapo-Transpiration (Global-PET) and Global Aridity Index (Global-Aridity) Geo-Database. CGIAR Consortium for Spatial Information. USDA Natural Resources Conservation Service, 1996. Soil Quality Indicators. Aggregate Stability.

Valentine, J.C., Pigott, T.D., Rothstein, H.R., 2010. How many studies do you need? A primer on statistical power for meta-analysis. J. Educ. Behav. Stat. 35, 215-247. https://doi.org/10.3102/1076998609346961.

van der Ent, R.J., Savenije, H.H.G., Schaefli, B., Steele-Dunne, S.C., 2010. Origin and fate of atmospheric moisture over continents. Water Resour. Res. 46. https://doi.org/10. 1029/2010WR009127.

Van Stan, J.T., Gordon, D.A., 2018. Mini-review: stemflow as a resource limitation to near-stem soils. Front. Plant Sci. 9. https://doi.org/10.3389/fpls.2018.00248.

Vanacker, V., Bellin, N., Molina, A., Kubik, P.W., 2014. Erosion regulation as a function of human disturbances to vegetation cover: a conceptual model. Landscape Ecol. 29, 293-309. https://doi.org/10.1007/s10980-013-9956-z.

Vanacker, V., von Blanckenburg, F., Govers, G., Molina, A., Poesen, J., Deckers, J., Kubik, P., 2007. Restoring dense vegetation can slow mountain erosion to near natural benchmark levels. Geology 35, 303-306. https://doi.org/10.1130/G23109A.1. 
Viechtbauer, W., 2010. Conducting meta-analyses in R with the metafor package. J. Stat. Softw. 36, 148.

Vorpahl, P., Dislich, C., Elsenbeer, H., Märker, M., Schröder, B., 2013. Biotic controls on shallow translational landslides. Earth Surf. Proc. Land. 38, 198-212. https://doi. org/10.1002/esp.3320.

Weigandt, M., Gyenge, J., Fernandez, M.E., Varela, S., Schlichter, T., 2011. Is forage productivity of meadows influenced by the afforestation of upstream hillsides? A study in NW Patagonia. For. Syst. 20, 165-175.

White, D.A., McGrath, J.F., Ryan, M.G., Battaglia, M., Mendham, D.S., Kinal, J., Downes, G.M., Crombie, D.S., Hunt, M.E., 2014. Managing for water-use efficient wood production in Eucalyptus globulus plantations. Forest Ecol. Manage. 331, 272-280. https://doi.org/10.1016/j.foreco.2014.08.020.

World Meteorological Organization, 2012. International Glossary of Hydrology. World Resources Institute, n.d. Initiative 20x20 [WWW Document]. World Resources Institute. URL<http://www.wri.org/our-work/project/initiative- 20x20>(accessed 5.11.18).

Zhang, L., Dawes, W.R., Walker, G.R., 2001. Response of mean annual evapotranspiration to vegetation changes at catchment scale. Water Resour. Res. 37, 701-708.

Zimmermann, B., 2007. Spatial and Temporal Variability of Soil Saturated Hydraulic Conductivity in Gradients of Disturbance (PhD Thesis). University of Postdam.

Zimmermann, B., Elsenbeer, H., 2009. The near-surface hydrological consequences of disturbance and recovery: a simulation study. J. Hydrol. 364, 115-127. https://doi. org/10.1016/j.jhydrol.2008.10.016.

Zuur, A.F. (Ed.), 2009. Mixed effects models and extensions in ecology with R, Statistics for biology and health. Springer, New York, NY. 